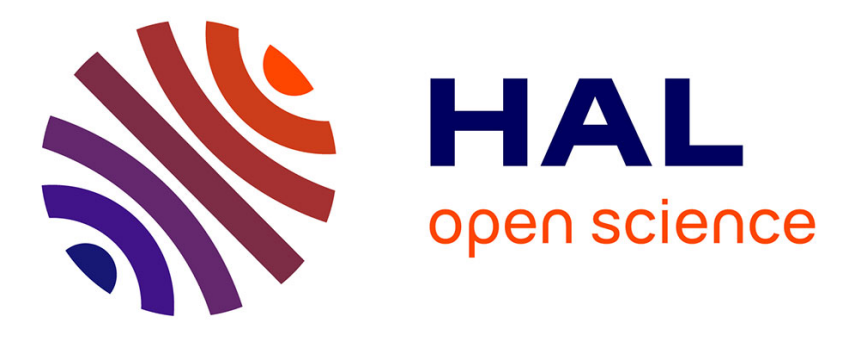

\title{
Comprehensive analysis of direct aqueous mineral carbonation using dissolution enhancing organic additives
}

Benjamin Bonfils, Carine Julcour-Lebigue, François Guyot, Françoise Bodénan, Pierre Chiquet, Florent Bourgeois

\section{To cite this version:}

Benjamin Bonfils, Carine Julcour-Lebigue, François Guyot, Françoise Bodénan, Pierre Chiquet, et al.. Comprehensive analysis of direct aqueous mineral carbonation using dissolution enhancing organic additives. International Journal of Greenhouse Gas Control, 2012, 9, pp.334-346. 10.1016/j.ijggc.2012.05.009 . hal-00773507

\section{HAL Id: hal-00773507 https: / hal-brgm.archives-ouvertes.fr/hal-00773507}

Submitted on 22 Nov 2018

HAL is a multi-disciplinary open access archive for the deposit and dissemination of scientific research documents, whether they are published or not. The documents may come from teaching and research institutions in France or abroad, or from public or private research centers.
L'archive ouverte pluridisciplinaire HAL, est destinée au dépôt et à la diffusion de documents scientifiques de niveau recherche, publiés ou non, émanant des établissements d'enseignement et de recherche français ou étrangers, des laboratoires publics ou privés. 


\section{Open Archive Toulouse Archive Ouverte (OATAO)}

OATAO is an open access repository that collects the work of Toulouse researchers and makes it freely available over the web where possible

This is an author's version published in: http://oatao.univ-toulouse.fr/21201

Official URL: https://doi.org/10.1016/j.ijggc.2012.05.009

\section{To cite this version:}

Bonfils, Benjamin $כ$ and Julcour-Lebigue, Carine François and Bodénan, Françoise and Chiquet, Pierre and

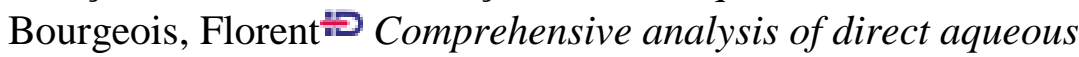
mineral carbonation using dissolution enhancing organic additives. (2012) International Journal of Greenhouse Gas Control, 9. 334-346. ISSN $1750-5836$

Any correspondence concerning this service should be sent to the repository administrator: tech-oatao@listes-diff.inp-toulouse.fr 


\title{
Comprehensive analysis of direct aqueous mineral carbonation using dissolution enhancing organic additives
}

\author{
Benjamin Bonfils ${ }^{\mathrm{a}}$, Carine Julcour-Lebigue ${ }^{\mathrm{b}}$, François Guyot $^{\mathrm{c}}$, Françoise Bodénan ${ }^{\mathrm{d}}$, \\ Pierre Chiquet ${ }^{\mathrm{e}}$, Florent Bourgeois ${ }^{\mathrm{a}, *}$ \\ a Université de Toulouse, Laboratoire de Génie Chimique, 4 allée Emile Monso - BP 84234, 31030 Toulouse Cedex 4, France \\ b CNRS, Laboratoire de Génie Chimique, 31030 Toulouse, France \\ ' Institut de Minéralogie et de Physique des Milieux Condensés (IMPMC) and Institut de Physique du Globe de Paris (IPGP), 4, Place Jussieu, 75005 Paris, France \\ d BRGM, 3 Av. C. Guillemin, BP 6009, 45060 Orléans Cedex 2, France \\ e Centre Scientifique et Technique Jean Feger, TOTAL, Avenue Larribau, 64018 Pau Cedex, France
}

\section{A R T I C L E I N F O}

Keywords:

Mineral carbonation

Magnesium silicate

Oxalate

Geochemical modelling

\begin{abstract}
A B S T R A C T
Direct aqueous mineral carbonation using organic anions has been presented by many as a promising strategy for mineral carbonation, on the basis that additives such as oxalate increase the rate and extent of dissolution of magnesium silicates several folds. Through geochemical modelling and detailed solid characterisation, this paper discusses and extends our current understanding of this process. The role of disodium oxalate as a dissolution enhancing agent for olivine is thoroughly examined through experiments in which all phases are carefully analysed. We show that under 20 bar of $\mathrm{CO}_{2}$ pressure formation of strong oxalate-magnesium complexes in solution and precipitation of $\mathrm{MgC}_{2} \mathrm{O}_{4} \cdot 2 \mathrm{H}_{2} \mathrm{O}$ (glushinskite) impede any chance of obtaining significant amounts of magnesium carbonate. Other promising ligands from a dissolution perspective, namely citrate and EDTA salts, are also investigated. Contrary to oxalate, these ligands do not form any solid by-products with magnesium, and yet they do not produce better carbonation results, thereby casting strong doubts on the possibility of developing a direct aqueous mineral carbonation process using organic salts. Geochemical modelling permits successful simulation of the dissolution kinetics of magnesium silicate using a shrinking particle model that accounts for the precipitation of glushinskite, amorphous silica and a magnesium phyllosilicate at advanced stages of the dissolution process.
\end{abstract}

\section{Introduction}

Ex situ mineral carbonation is considered a possible alternative to geological storage for $\mathrm{CO}_{2}$ mitigation (Metz et al., 2005). Its strongest asset is that it converts a $\mathrm{CO}_{2}$ gas stream into stable solid carbonates. Mineral carbonation was first investigated under dry conditions, however kinetics was invariably found to be slow for consideration as an ex situ process (Lackner et al., 1995). Then, investigations shifted almost entirely towards aqueous mineral carbonation, with two distinct schools of thought. The first one seeks to develop an indirect process with two sequential steps (Newall et al., 1999; Park and Fan, 2004; Teir et al., 2007), which can be optimised separately. The first step is the dissolution of ( $\mathrm{Mg}, \mathrm{Ca}$ )-bearing solids - either naturally occurring such as $(\mathrm{Mg}, \mathrm{Ca})$ silicates, or industrially produced such as mining wastes or slags - under strongly acidic conditions, followed by a carbonate precipitation step under basic conditions. The most severe problems

\footnotetext{
* Corresponding author. Tel.: +33 534323633; fax: +33 534323700 .

E-mail address: florent.bourgeois@inp-toulouse.fr (F. Bourgeois).
}

with this process include a considerable consumption of acids and bases, and, to a lesser extent, a potentially high energy requirement for the recycling of consumables (Newall et al., 1999). The second school of thought, to which this work belongs, seeks to develop a direct process whereby dissolution of (Mg,Ca)-bearing solids and precipitation of carbonates occur under the same narrow near-neutral $\mathrm{pH}$ range imposed by the process itself ( $\mathrm{O}$ 'Connor et al., 2001; Gerdemann et al., 2007). The basis for this possibility is the demonstration by a number of research teams that a number of specific catalyst-like additives can accelerate silicate dissolution significantly under mild operating conditions (O'Connor et al., 2001; Krevor and Lackner, 2009, 2011).

Studies from NETL (O'Connor et al., 2001; Chen et al., 2006; Gerdemann et al., 2007) paved the way for direct aqueous carbonation of magnesium silicates with additives; mainly, they aimed to quantify the overall process costs, and to obtain the highest possible extent of reaction. Their work was based on a solution with $0.64 \mathrm{M} \mathrm{NaHCO}_{3}$ and $1 \mathrm{M} \mathrm{NaCl}$ (O'Connor et al., 2001) under a $\mathrm{CO}_{2}$ pressure of $170 \mathrm{~atm}$ and $180^{\circ} \mathrm{C}$. Comprehensive insights about the effect of these inorganic additives are given by Chen et al. (2006). Gerdemann et al. (2007) obtained high conversion ( $80 \%$ of olivine in 


\begin{tabular}{|c|c|}
\hline \multicolumn{2}{|c|}{ Nomenclature } \\
\hline$a_{\mathrm{ox}}$ & activity of oxalate ion (-) \\
\hline$a_{\mathrm{H}^{+}}$ & activity of proton $(-)$ \\
\hline$K_{\mathrm{H}^{+}}$ & apparent adsorption constant of proton $(-)$ \\
\hline$K_{\mathrm{s}}$ & solubility constant (-) \\
\hline$k_{\mathrm{SiO}_{2(\mathrm{am})}}$ & kinetic constant of $\mathrm{SiO}_{2(\mathrm{am})}$ precipitation $\left(\right.$ molal s$\left.{ }^{-1}\right)$ \\
\hline$k_{\text {talc }}$ & kinetic constant of talc precipitation (molal s ${ }^{-1}$ ) \\
\hline$K_{x}$ & apparent adsorption constant of oxalate ion (-) \\
\hline$m_{\mathrm{ox}}$ & $\begin{array}{l}\text { concentration of oxalate ion (molal or } \mathrm{mol} \mathrm{kg}^{-1} \text { sol- } \\
\text { vent) }\end{array}$ \\
\hline \multicolumn{2}{|c|}{$m_{\mathrm{SiO}_{2(\mathrm{am})}}$ concentration of amorphous silica (molal) } \\
\hline$m_{\text {talc }}$ & concentration of talc (molal) \\
\hline$n_{B}$ & $\begin{array}{l}\text { number of moles of olivine (in considered size class) } \\
\text { at a given time ( } \mathrm{mol} \text { ) }\end{array}$ \\
\hline$Q$ & reaction quotient $(-)$ \\
\hline$r$ & specific dissolution rate $\left(\mathrm{mol} \mathrm{m}^{-2} \mathrm{~s}^{-1}\right)$ \\
\hline$r_{\mathrm{H}^{+}}$ & $\begin{array}{l}\text { specific dissolution rate due to surface protonation } \\
\text { alone (ligand free system) }\left(\mathrm{mol} \mathrm{m}^{-2} \mathrm{~s}^{-1}\right)\end{array}$ \\
\hline $\mathrm{SSA}_{0}$ & $\begin{array}{l}\text { initial specific surface area of monodisperse particle } \\
\text { class }\left(\mathrm{m}^{2} \mathrm{~g}^{-1}\right)\end{array}$ \\
\hline$w_{0}$ & initial weight of considered size class ( $\mathrm{g}$ ) \\
\hline$\beta$ & kinetic parameter measuring the ligand effect $(-)$ \\
\hline$\Omega$ & saturation index $(-)$ \\
\hline
\end{tabular}

$6 \mathrm{~h}$ ) with the $\mathrm{NaHCO}_{3} / \mathrm{NaCl}$ system at high $\mathrm{CO}_{2}$ pressures and temperatures, along with thermal pretreatment and very fine grinding of magnesium silicates.

Other research teams directed their attention to organic ligands to further accelerate silicate dissolution (Olsen and Rimstidt, 2008; Krevor and Lackner, 2009, 2011; Prigiobbe and Mazzotti, 2011), on the basis that this approach could potentially reduce some of the penalties associated with inorganic ligands, and yield comparable conversion and kinetics with coarser particles. In this context, it is important to note that carbonate precipitation is controlled by thermodynamics and occurs instantaneously as soon as the oversaturation needed for carbonate nucleation is reached (Hänchen et al., 2008). A number of authors, including Huijgen et al. (2006), Béarat et al. (2006) and Daval et al. (2009), showed that magnesium silicate dissolution is the rate-limiting step with respect to the overall carbonation process, especially under near-neutral $\mathrm{pH}$ conditions where proton concentration, the dissolution driver, is very low. This explains why most kinetic studies to date have logically been focusing on the dissolution step.

Krevor and Lackner $(2009,2011)$ have made a definite contribution to the advancement of dissolution kinetics of magnesium silicates using organic salts in the context of direct aqueous mineral carbonation. Using a serpentine antigorite ore, they chose to operate at a temperature of $120^{\circ} \mathrm{C}$, a $\mathrm{CO}_{2}$ pressure of $20 \mathrm{bar}$, and a solid concentration of $3 \mathrm{~g} \mathrm{l}^{-1}$ with ground particles ground. In their most recent work (2011), they used particles with mean volume diameter as large as $200 \mu \mathrm{m}$. Their choosing a low solid concentration was intended to prevent precipitation of magnesite, which is justified by the dissolution focus of their work. By monitoring changes in magnesium concentration in solution during reaction, they obtained significantly higher initial dissolution rates with oxalate, citrate and EDTA ligands than with inorganic salts. After $24 \mathrm{~h}$, they found that $70 \%$ of the Mg contained in the serpentine particles had leached into solution. Overall, their results proved and quantified the efficacy of polyacid organic salts on the dissolution kinetics of magnesium silicates.

Since their work relied upon analysis of the liquid phase only, their results however do not provide a clear picture of the changes that may occur in the solid phase. In particular, it is not known whether magnesium carbonates may have formed during their experiments, however unlikely this may be given the low solid concentration and $\mathrm{CO}_{2}$ partial pressure they used. The dissolution focus of their research did not permit their concluding about possible limitations of the direct aqueous carbonation process. In particular, it is not possible from their data to assess the availability of dissolved magnesium to form magnesium carbonates, recalling that the very principle of the direct aqueous carbonation process is to allow the dissolution of silicates and the precipitation of carbonates to coexist under the same near-neutral $\mathrm{pH}$ (or weakly acidic) conditions. One contribution of the present work is to complete their findings with the analysis of the solid phase, in conjunction with that of the species in solution, and find out whether operating conditions exist whereby dissolved magnesium in solution is available to form magnesium carbonates.

The interactions between a number of organic ligands and magnesium silicates have received a great deal of attention in the geochemical literature (Wogelius and Walther, 1991; Hänchen et al., 2006; Liu et al., 2006; Olsen and Rimstidt, 2008) since it is also a natural weathering mechanism for silicates. Olsen and Rimstidt (2008) conclude that the oxalate ion accelerates forsterite leaching by protons (dissociation of $\mathrm{Mg}-\mathrm{O}-\mathrm{Si}$ bonds). It is purely a surface mechanism in which the oxalate ion bonds with the Mg atom, which weakens the $\mathrm{Mg}-\mathrm{O}$ bond more efficiently than water alone, thereby increasing dissolution kinetics. This implies that ion concentration, relative to the reactive surface area of particles, is a key parameter for the dissolution of magnesium. Finally, we may add that formation of $\mathrm{Si}$-oxalate complexes, in solution and/or at the surface, has also been suggested to explain the improved kinetics of quartz dissolution with these ligands (Bennett, 1991). Si-oxalate complexes could therefore possibly contribute to the overall dissolution of magnesium silicates, although their formation remains controversial (Poulson et al., 1997).

Quantification of dissolution kinetics has also received some attention in the literature in relation to aqueous mineral carbonation. Under highly acidic conditions $\left(2 \mathrm{M} \mathrm{HCl}, \mathrm{H}_{2} \mathrm{SO}_{4}\right.$ or $\left.\mathrm{HNO}_{3}\right)$, Teir et al. (2007) explained their magnesium dissolution measurements from monodisperse serpentine particles $\left(20 \mathrm{gl}^{-1}\right)$ using a shrinking core model, where diffusion in an alteration layer is the rate-controlling step. In the presence of organic ligands such as citrate salt, Krevor and Lackner (2011) fitted a shrinking particle model to their dissolution data with serpentine particles and showed that surface reaction controlled the extraction rate of magnesium. They observed the stoichiometric congruence of silicium and magnesium dissolution until silicium concentration reached about $90 \mathrm{ppm}$ in solution (equivalent to a dissolved fraction of $60 \mathrm{wt} . \%$ in the conditions of the authors). Past this point, aqueous silicium concentration drops and stabilises to a level that is controlled by the solubility of silica under the conditions of the tests. Olsen and Rimstidt (2008) expressed the oxalate-promoted dissolution rate of olivine by adding a term to the proton-driven dissolution model:

$r=10^{-7.03} a_{\mathrm{H}^{+}}^{0.46}+10^{-5.44} m_{\mathrm{ox}}^{0.40} a_{\mathrm{H}^{+}}^{0.47}$

In Eq. (1), $r$ is the specific dissolution rate $\left(\mathrm{mol} \mathrm{m}^{-2} \mathrm{~s}^{-1}\right)$ measured at $25^{\circ} \mathrm{C}, m_{\mathrm{ox}}$ the concentration of oxalate ion in molal, and $a_{\mathrm{H}^{+}}$the activity of the hydrogen ion. Prigiobbe and Mazzotti (2011) also considered dissolution to occur as two parallel reactions; however they chose a surface complexation model based on Langmuir adsorption isotherm to describe the same rate dependence:

$r=\left(\frac{r_{\mathrm{H}^{+}}}{1+K_{\mathrm{H}^{+}} a_{\mathrm{H}^{+}}^{n}}\right)\left(\frac{1+\beta K_{x} a_{\mathrm{ox}}}{1+K_{x} a_{\mathrm{ox}}}\right)$ 


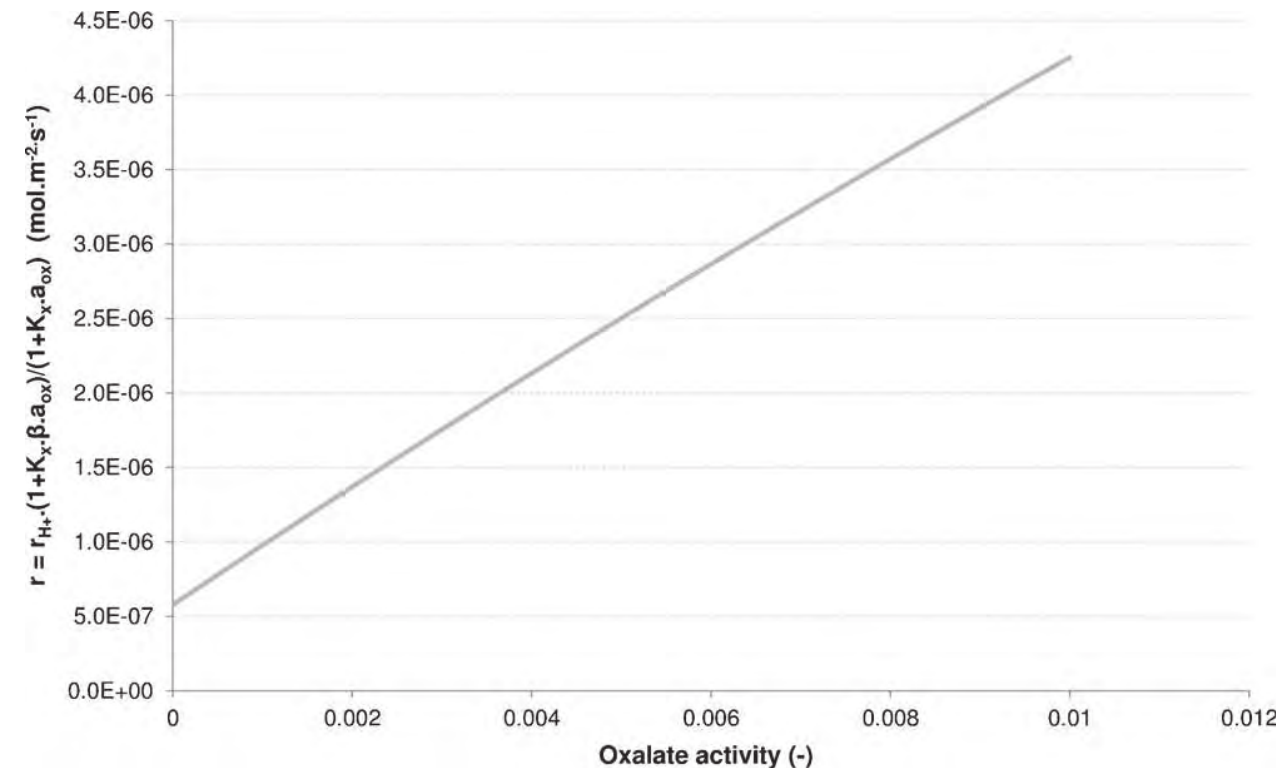

Fig. 1. Oxalate-promoted dissolution rate at $120^{\circ} \mathrm{C}$ according to the rate law given by Prigiobbe and Mazzotti (2011): evolution as a function of oxalate activity in solution (with constant proton activity set to $8.7 \times 10^{-6}$, rate without additive being $r_{\mathrm{H}^{+}}=5.8 \times 10^{-7} \mathrm{~mol} \mathrm{~m}^{-2} \mathrm{~s}^{-1}$ ).

In Eq. (2), $K_{\mathrm{H}^{+}}$and $K_{x}$ are the apparent adsorption constants for proton and oxalate ion, respectively, $a_{\mathrm{ox}}$ the activity of oxalate ion, $\beta$ a kinetic parameter accounting for the ligand effect and $r_{\mathrm{H}^{+}}$the specific dissolution rate due to surface protonation alone (ligand free system) which is $n$th order with respect to the activity of proton $a_{\mathrm{H}^{+}}$:

$r_{\mathrm{H}^{+}}=a_{\mathrm{H}^{+}}^{n} A e^{-E_{a} / R T}$

Since $K_{\mathrm{H}^{+}}$is small, it is noted that the denominator in the first term in Eq. (2) is approximately equal to unity. Fig. 1 shows the evolution of the dissolution rate according to Eq. (2), as a function of the activity of oxalate in solution. It shows the sensitivity of dissolution kinetics with respect to variations in the concentration of oxalate in solution.

The present work also deals with direct aqueous mineral carbonation using organic salts. It aims to fill some of the current knowledge gaps of this process and shed new light on its actual potential as a $\mathrm{CO}_{2}$ mitigation process. Magnesium silicates being more abundant a raw material than calcium silicates (Goff and Lackner, 1998; Goff et al., 2000), results and discussions presented in the paper are limited to the case of magnesium.

\section{Experimental analysis}

\subsection{Experimental set-up and materials}

Experiments were performed at $120^{\circ} \mathrm{C}$ under 20 bar of $\mathrm{CO}_{2}$ with different solid (slurry) concentrations ranging from $3 \mathrm{gl}^{-1}$ water (0.3 wt.\%) as per Krevor and Lackner (2011) to $250 \mathrm{~g} \mathrm{l}^{-1}$ water (20 wt.\%). They were carried out using either osmosed water or $0.1 \mathrm{M}$ disodium oxalate solution (Sigma-Aldrich, purity $\geq 99.5 \%$ ). The choice of oxalate concentration was initially guided by the work of Krevor and Lackner (2009).

The experimental set-up consisted of a $300 \mathrm{~mL}$ stirred autoclave reactor with a Teflon inner jacket and Hastelloy internals. The $\mathrm{CO}_{2}$ pressure inside the reactor was regulated using a $\mathrm{CO}_{2}$ ballast tank, and instantaneous $\mathrm{CO}_{2}$ consumption by the reaction was monitored by recording total pressure and temperature inside the ballast: the Peng-Robinson equation of state for $\mathrm{CO}_{2}$ was used to convert the pressure and temperature data into the actual number of moles in the ballast tank during the experiment. The slurry was stirred by a gas inducing turbine that achieved fast $\mathrm{CO}_{2}$ transfer into the liquid phase, $\mathrm{CO}_{2}$ being the only gas added into the system. Slurry temperature was monitored and controlled by a standard PID controller. A typical test run consisted in contacting $\mathrm{CO}_{2}$ with the liquid-solid dispersion under constant pressure for $24 \mathrm{~h}$. After reaction, two alternative sampling procedures were used:

- Sampling procedure (1): At the end of the reaction time, the system is cooled down to room temperature and pressure is released. The typical duration of this step is $20 \mathrm{~min}$. The slurry is then passed through a $0.2 \mu \mathrm{m}$ filter for solution analysis and retained solids are oven dried.

- Sampling procedure (2): At the end of the reaction time, the liquid is entirely and rapidly drawn from the reactor through a dip tube fitted with a $2 \mu \mathrm{m}$ stainless steel filter prior to cooling. This experimental protocol is used to capture the state of the reactive system at its operating temperature and pressure. Upon drying of the solids, analysis of liquid and solid phases gives the full composition of the system at the reaction temperature $\left(120^{\circ} \mathrm{C}\right)$.

$\mathrm{Mg}$ and $\mathrm{Si}$ concentrations in the filtrate were measured by inductively coupled plasma atomic emission spectroscopy (ICPAES). Solid phase characterisation was done by several techniques: microscopy (field emission gun scanning electron microscopy (FEG/SEM) coupled with energy dispersive X-ray (EDX) analysis), $\mathrm{X}$-ray diffraction, Raman and infrared (IR) spectroscopies and thermogravimetry (TG coupled with IR analysis of released gases).

Thermogravimetry analysis, performed under $\mathrm{N}_{2}$ flow (with a heating rate of $10^{\circ} \mathrm{Cmin}^{-1}$ from room temperature to $1000^{\circ} \mathrm{C}$, including $30 \mathrm{~min}$ plateau at $120^{\circ} \mathrm{C}$ to remove adsorbed water), yielded the total amount of $\mathrm{CO}_{2}$ in the solids after reaction. From analysis of TG/IR spectra for the initial material and a pure magnesite standard, it was found that carbonates formed during reaction could be detected and quantified by the TG weight loss in the temperature range $300-600^{\circ} \mathrm{C}$. TG/IR analysis was also used to quantify the amount of solid by-products, such as oxalate magnesium dihydrate, which first releases $\mathrm{H}_{2} \mathrm{O}$ in the $120-300^{\circ} \mathrm{C}$ range, then $\mathrm{CO}$ and $\mathrm{CO}_{2}$ in a similar temperature range as magnesite, between 300 and $600^{\circ} \mathrm{C}$.

The investigated material from Magnolithe GmbH (Austria) called hereafter 'olivine' is mainly composed of forsteritic olivine. 
Table 1

Mineral composition of investigated olivine, given as oxide wt.\%. Iron is given as $\mathrm{Fe}_{2} \mathrm{O}_{3}$ for convenience.

\begin{tabular}{lc}
\hline & Content (wt.\%) \\
\hline $\mathrm{SiO}_{2}$ & 42.2 \\
$\mathrm{Al}_{2} \mathrm{O}_{3}$ & 0.5 \\
$\mathrm{CaO}$ & 0.2 \\
$\mathrm{MgO}$ & 46.4 \\
$\mathrm{MnO}$ & 0.1 \\
$\mathrm{Fe}_{2} \mathrm{O}_{3}$ & 9.8 \\
Loss on ignition & 0.1 \\
\hline
\end{tabular}

The material also contains minor amounts of clinoenstatite, chromite and magnetite. Total Mg content potentially available for carbonation expressed as $\mathrm{MgO}$ is $46.4 \%$ (Table 1 ). This olivine is produced by processing the natural material - serpentinised dunite at high temperature. During this process serpentine is deshydroxylated and some iron forms magnetite inclusions. It also contains a minor amount of chromite. Such a material might be representative of metallurgically processed ultrabasic materials.

This raw material was dry ground using a laboratory ball mill, then sieved below $100 \mu \mathrm{m}$ and sampled using a rotary splitter. This procedure resulted in lots with $0.58 \mathrm{~m}^{2} \mathrm{~g}^{-1}$ BET surface area (measured by krypton adsorption) and $12.1 \mu \mathrm{m}$ surface area mean (Sauter) diameter. The full particle size distribution measured by a Malvern Mastersizer 2000 is plotted in Fig. 2.

When used in the geochemical simulation section of this work, the size distribution measured by laser diffractometry, which comprises 100 size classes was discretised into 20 size classes with equal contribution to the overall surface-weighted particle size distribution. Properties of these 20 size classes (mean diameter, cumulative fraction by mass and by surface, and corresponding calculated specific surface area) are given for reference in Table 2. It was verified that the total specific surface area for the 20 size classes adds up to the experimental BET value of $0.58 \mathrm{~m}^{2} \mathrm{~g}^{-1}$ measured by krypton adsorption.

\subsection{Experimental results and discussion}

\subsubsection{Dissolution of olivine with oxalate salt under dilute slurry condition}

As expected from the results of Krevor and Lackner (2011), the experiment carried under dilute slurry condition $\left(3 \mathrm{gl}^{-1}\right)$ did not form any magnesite. However, we identified the presence of a solid by-product distinct from the olivine particles, as noted by Carey
Table 2

Size distribution and corresponding specific surface areas for the model olivine used in the simulation work.

\begin{tabular}{rlll}
\hline $\begin{array}{l}\text { Mean diameter } \\
\text { (micron) }\end{array}$ & $\begin{array}{l}\text { Cumulative } \\
\text { passing } \\
\text { fraction by } \\
\text { mass }(-)\end{array}$ & $\begin{array}{l}\text { Cumulative } \\
\text { passing } \\
\text { fraction by } \\
\text { surface }(-)\end{array}$ & $\begin{array}{l}\text { Calculated } \\
\text { specific surface } \\
\text { area }\left(\mathrm{m}^{2} \mathrm{~g}^{-1}\right)\end{array}$ \\
\hline 224.4 & 1 & 1 & 0.08 \\
56.5 & 0.64 & 0.95 & 0.15 \\
35.1 & 0.46 & 0.9 & 0.24 \\
22.2 & 0.34 & 0.85 & 0.38 \\
14.9 & 0.26 & 0.8 & 0.54 \\
10.9 & 0.21 & 0.75 & 0.72 \\
8.4 & 0.17 & 0.7 & 0.92 \\
6.7 & 0.14 & 0.65 & 1.15 \\
5.4 & 0.11 & 0.6 & 1.40 \\
4.4 & 0.091 & 0.55 & 1.71 \\
3.7 & 0.074 & 0.5 & 2.03 \\
3.1 & 0.06 & 0.45 & 2.42 \\
2.6 & 0.048 & 0.4 & 2.82 \\
2.2 & 0.037 & 0.35 & 3.36 \\
1.9 & 0.029 & 0.3 & 3.89 \\
1.6 & 0.021 & 0.25 & 4.58 \\
1.4 & 0.015 & 0.2 & 5.42 \\
1.2 & 0.0097 & 0.15 & 6.50 \\
0.9 & 0.0053 & 0.1 & 8.07 \\
0.7 & 0.0017 & 0.05 & 16.99 \\
\hline
\end{tabular}

et al. (2004). This product decomposes as $\mathrm{H}_{2} \mathrm{O}, \mathrm{CO}$ and $\mathrm{CO}_{2}$ under TG/IR conditions. Raman and infrared spectroscopies, as well as $\mathrm{X}$-ray diffraction, all confirmed this precipitate to be magnesium oxalate dihydrate $\left(\mathrm{MgC}_{2} \mathrm{O}_{4} \cdot 2 \mathrm{H}_{2} \mathrm{O}\right)$. Fig. 3 shows that Raman spectrum of final solid product coincides with that of $\mathrm{MgC}_{2} \mathrm{O}_{4} \cdot 2 \mathrm{H}_{2} \mathrm{O}$ (D'Antonio et al., 2010), while the characteristic peak of magnesite is not detected. The X-ray diffractogram shown in Fig. 4 indicates that the main polymorphic form is $\alpha-\mathrm{MgC}_{2} \mathrm{O}_{4} \cdot 2 \mathrm{H}_{2} \mathrm{O}$, also known as synthetic glushinskite.

Glushinskite particles of rhombohedral shape are also clearly visible in SEM images of reaction products (Fig. 9).

The actual amount of glushinskite that precipitated could be estimated directly from the thermogram (Fig. 5), since its thermal decomposition yields two successive mass losses $\left(\mathrm{H}_{2} \mathrm{O}\right.$, then $\mathrm{CO}+\mathrm{CO}_{2}$ ) with the characteristic ratio of 2 . Because thermal decomposition of glushinskite and carbonates overlap in the $300-600^{\circ} \mathrm{C}$ range, quantification of glushinskite was actually based on the first water mass loss. Additional mass loss in the $300-600{ }^{\circ} \mathrm{C}$ range was attributed to carbonates.

As it was not possible to measure $\mathrm{pH}$ inside the pressurised reactor, geochemical simulation was used to estimate $\mathrm{pH}$ and ionic

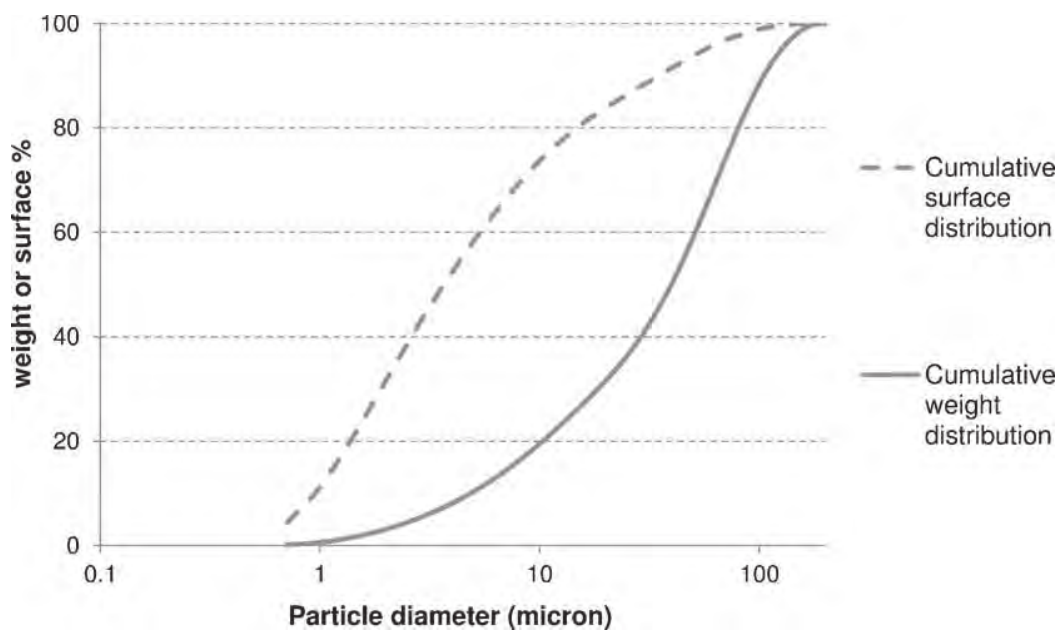

Fig. 2. Cumulative particle size distribution by mass and by surface for ground olivine sieved under $100 \mu \mathrm{m}$. 


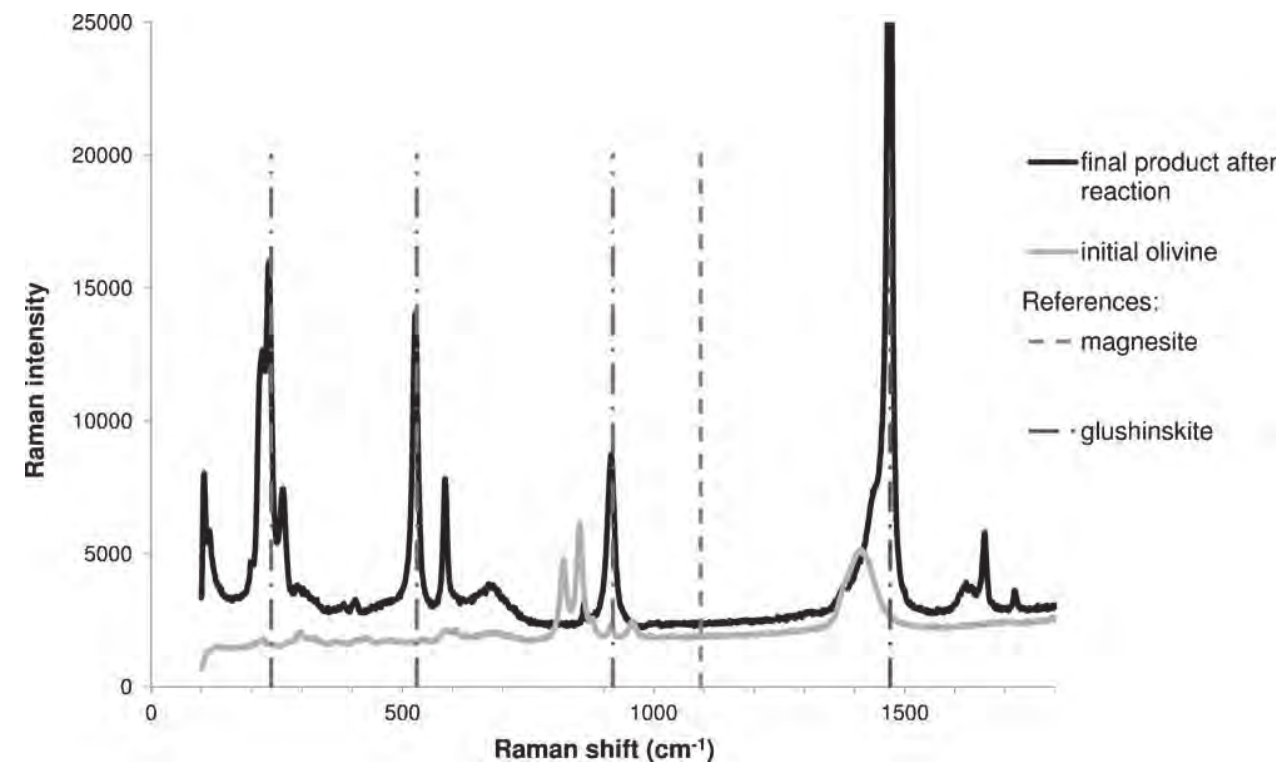

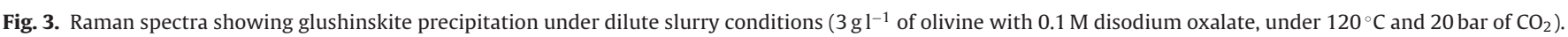

strength values, respectively, between 5 and 5.8 and between 0.29 and 0.27 molal during the course of reaction. In the liquid phase, magnesium speciation was completed by ICP/AES analysis. A total of $83 \%$ of magnesium was extracted in the $3 \mathrm{gl}^{-1}$ experiment, of which $25 \%$ was in the aqueous phase and the remaining $75 \%$ as glushinskite. As no quantitative amount of carbonates precipitated under such dilute conditions, other experiments were eventually carried out at higher slurry concentrations. Their intent was to exceed saturation of magnesite in solution and possibly form magnesite, as per the objective of direct aqueous carbonation of magnesium silicates.

\subsubsection{Effect of slurry concentration on olivine dissolution with} oxalate salt

The dilute $\left(3 \mathrm{gl}^{-1}\right)$ test condition did not yield any carbonate precipitation. This indicates that conditions were such that the $\mathrm{Mg}^{2+}$ concentration in solution did not exceed the magnesite saturation, due to an insufficient amount of magnesium in water and/or

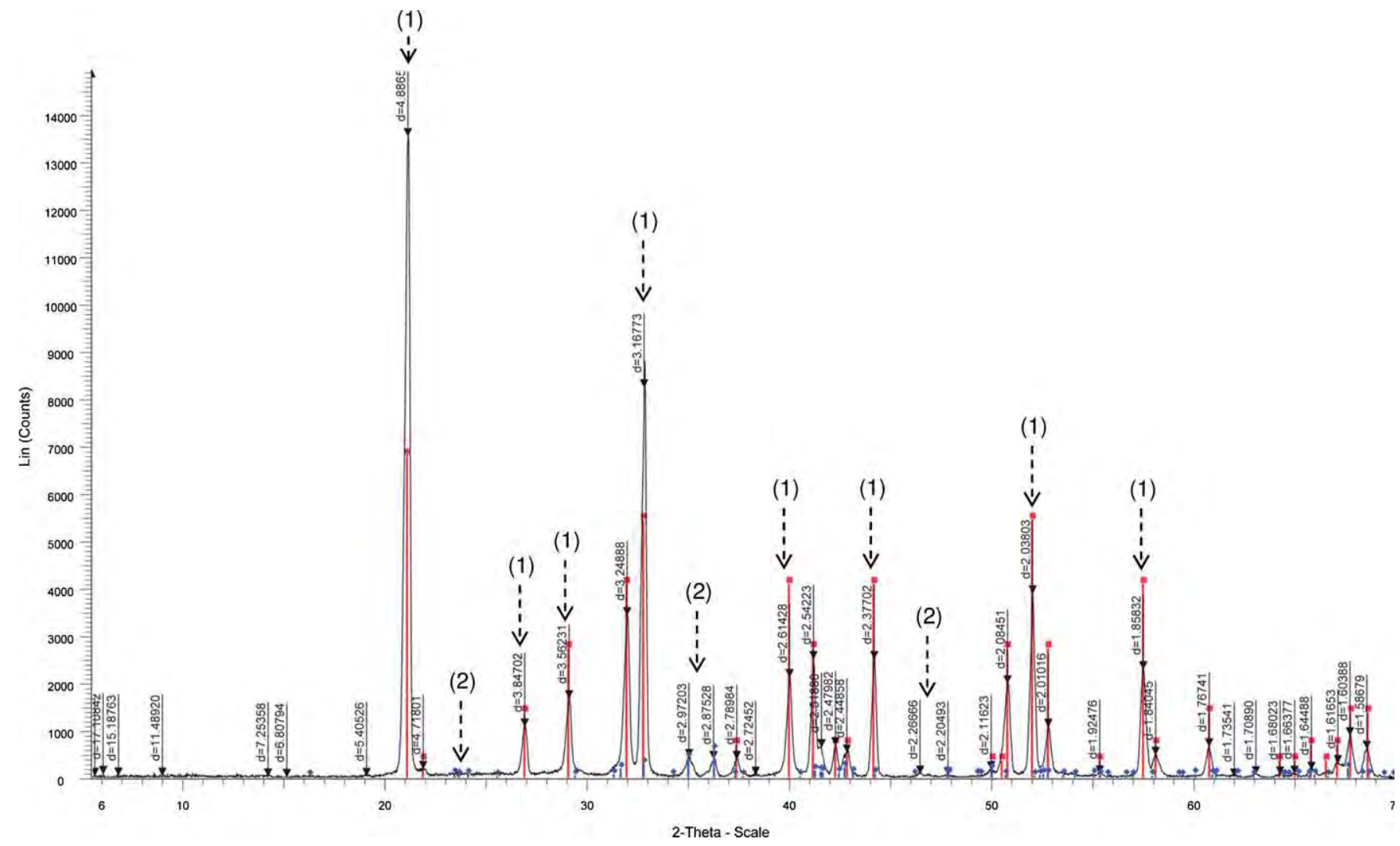

Fig. 4. X-ray diffraction pattern of final solid product under dilute slurry conditions $\left(3 \mathrm{gl}^{-1}\right.$ of olivine with $0.1 \mathrm{M}$ disodium oxalate, $120{ }^{\circ} \mathrm{C}$ and 20 bar of $\left.\mathrm{CO}_{2}\right)$. ( 1 ) $\alpha$ $\mathrm{MgC}_{2} \mathrm{O}_{4} \cdot 2 \mathrm{H}_{2} \mathrm{O}$ (23-0394) or synthetic glushinskite, (2) clinoenstatite (35-0610) (traces) from initial material. 


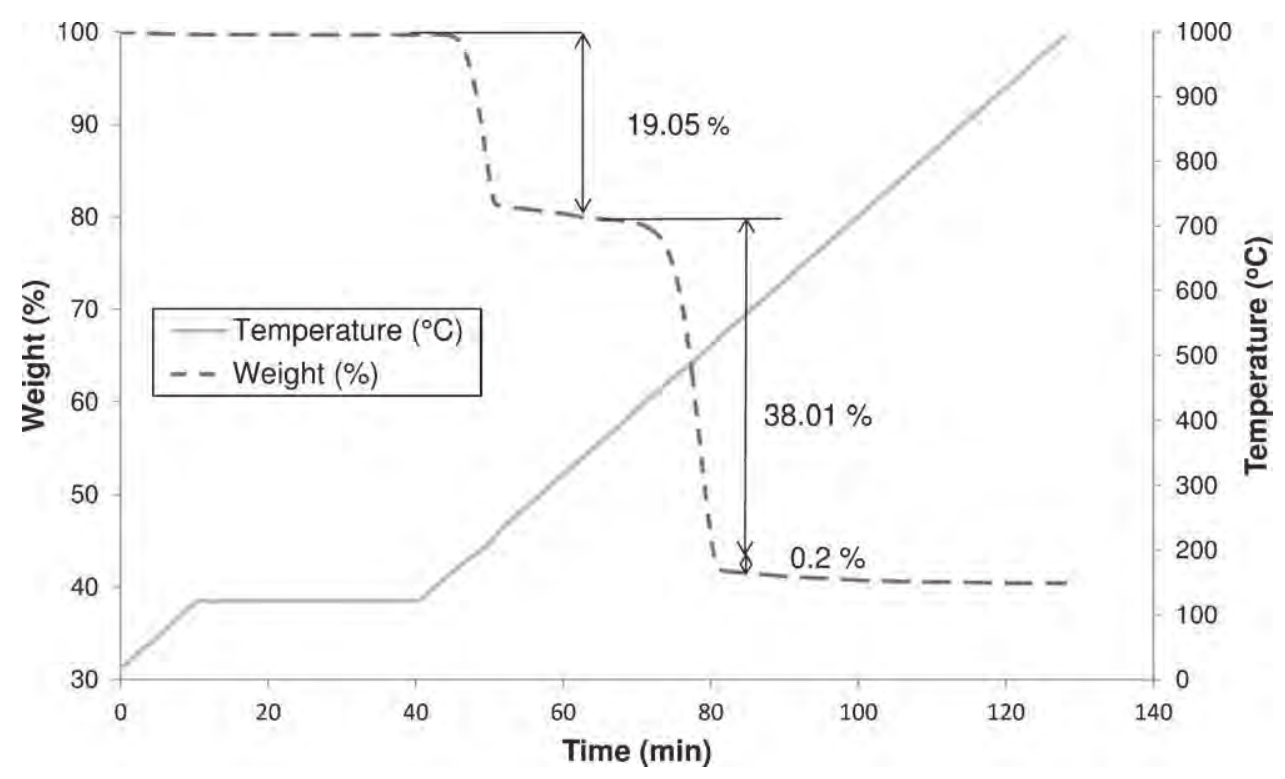

Fig. 5. Thermogravimetric analysis of final solid product consisting mainly of magnesium oxalate dihydrate. Two characteristic mass losses are observed: between $120{ }^{\circ} \mathrm{C}$ and $300^{\circ} \mathrm{C}$ water is released; between $300^{\circ} \mathrm{C}$ and $600^{\circ} \mathrm{C}$ dehydrated oxalate decomposes into $\mathrm{CO}_{2}$ and $\mathrm{CO}$.

its forming aqueous complexes with the oxalate ligand. As a result, a series of experiments was carried out from dilute $3 \mathrm{gl}^{-1}(0.3 \mathrm{wt} . \%)$ to concentrated $250 \mathrm{gl}^{-1}$ (20 wt.\%) conditions, at $120^{\circ} \mathrm{C}$ and with 20 bar of $\mathrm{CO}_{2}$ pressure. We note in passing that the dense slurry conditions are also more compliant with industrial process conditions.

Results for magnesium extraction and speciation after $24 \mathrm{~h}$ of reaction are illustrated in Fig. 6 . These measurements are those obtained after rapid cooling of the whole system before separation of solid and liquid phases, as per sampling procedure (1) (Section 2.1). Therefore, these experiments yield the system composition after rapid cooling to room temperature following the $24 \mathrm{~h}$ of reaction.

For a given concentration in oxalate salt, the material conversion decreases monotonically with increasing slurry concentration. At $250 \mathrm{gl}^{-1}, 70 \%$ of the oxalate precipitates as glushinskite, against $20 \%$ only at $3 \mathrm{gl}^{-1}$. This indicates that the concentration of free oxalate falls very rapidly in the former case (glushinskite precipitation occurring as soon as saturation of the species is reached), resulting in a significant slowing down of dissolution kinetics as illustrated in Fig. 1 and as predicted from rate equations (1) and (2). This also means that no compromise was found between the magnesium extraction yield and the amount of glushinskite formed while increasing slurry concentration, and magnesite saturation was never reached. In other words, the very low conversion obtained with the concentrated slurry at the same oxalate concentration did not yield a concentration in free magnesium high enough to exceed magnesite saturation.

With experiments at slurry concentration below $30 \mathrm{gl}^{-1}$, traces of carbonates were identified by IR spectroscopy and XRD analysis. Their amount was not sufficient, however, for reliable quantification by thermogravimetric analysis (accounting for less than $0.7 \%$ of initial magnesium).
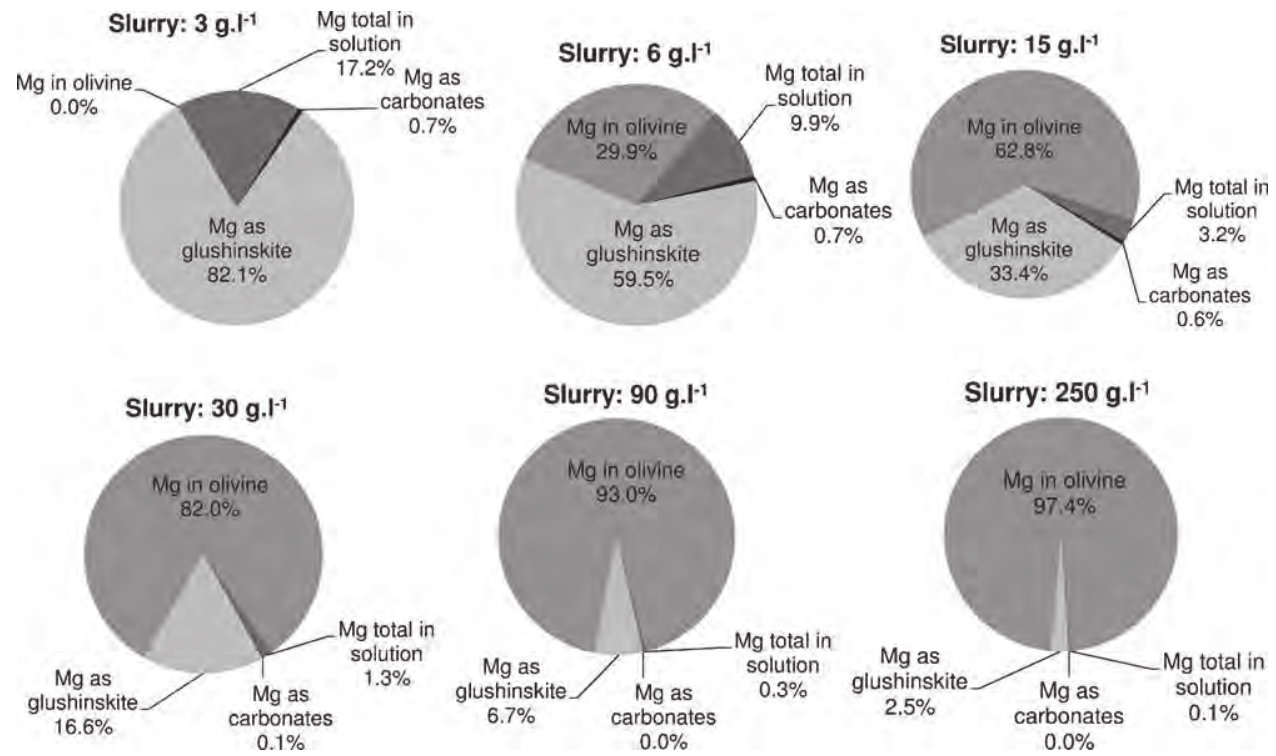

Fig. 6. Magnesium speciation as a function of slurry concentration after $24 \mathrm{~h}$ of batch reaction $\left(0.1 \mathrm{M}\right.$ disodium oxalate, $120{ }^{\circ} \mathrm{C}, 20$ bar of $\mathrm{CO}_{2}$, initial particle size below $100 \mu \mathrm{m})$. 

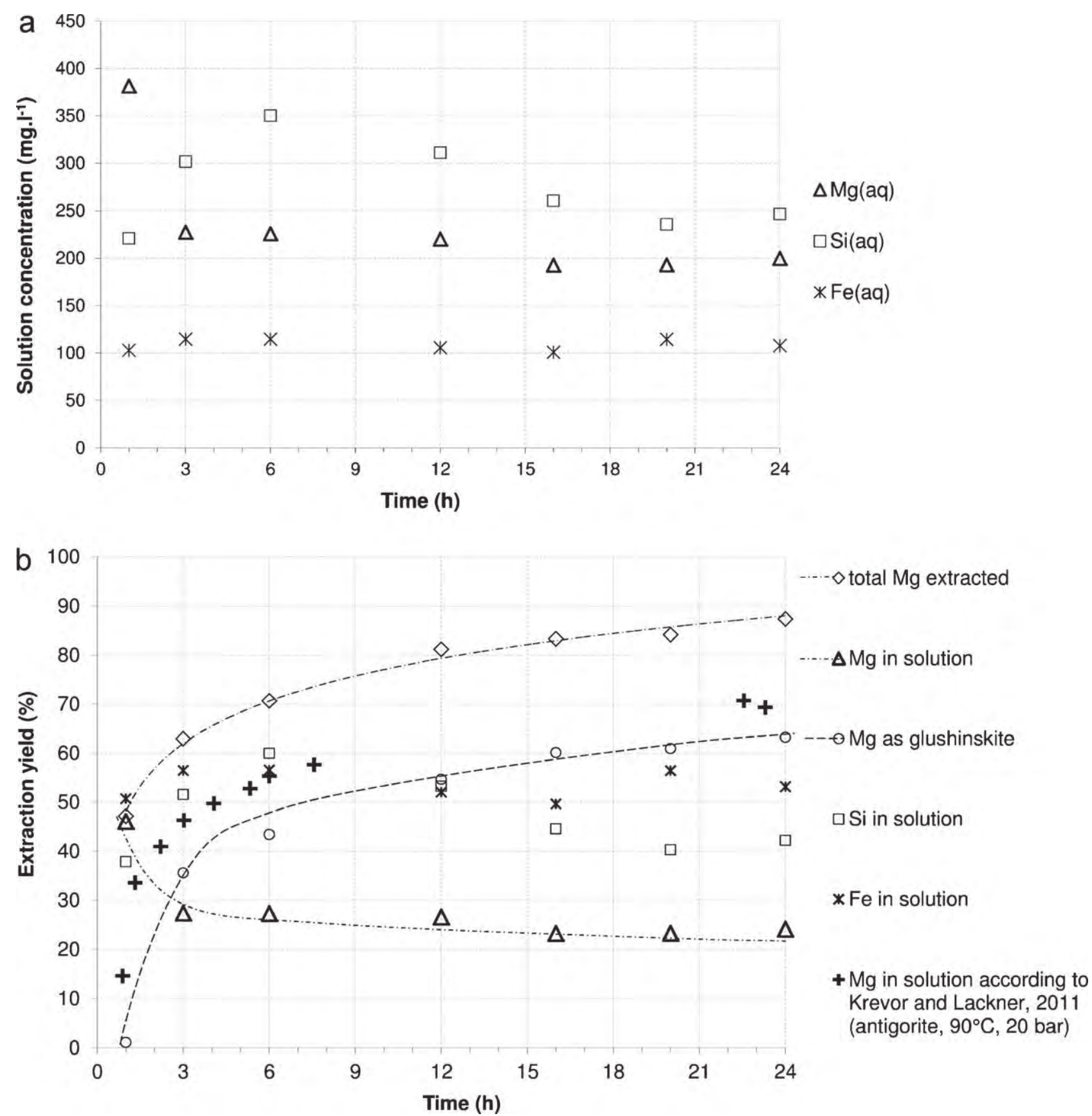

Fig. 7. Evolution of aqueous species concentration ( $\mathrm{Mg}$, Fe and $\mathrm{Si}$ ) (a) and of extraction yields with Mg speciation (b) ( $3 \mathrm{gl}^{-1}$ olivine slurry with $0.1 \mathrm{M}$ oxalate salt, under $120^{\circ} \mathrm{C}$ and 20 bar of $\mathrm{CO}_{2}$ ).

None of the conditions investigated resulted in any significant amount of carbonates in $24 \mathrm{~h}$, either due to the preferential formation of magnesium oxalate species - as glushinskite and aqueous complex (for $3 \mathrm{gl}^{-1}$ slurry), or because of a low dissolution yield (for $250 \mathrm{gl}^{-1}$ slurry). From a process perspective, these results show that the oxalate ligand is not a solution for direct aqueous mineral carbonation, as initially envisaged by Krevor and Lackner (2011).

\subsubsection{Dissolution kinetics study}

As discussed above and in previous communications (Bonfils et al., 2010, 2011), monitoring dissolution kinetics of such complex geochemical systems requires analysis of both liquid and solid phases. Since the solid phase cannot be sampled easily from the pressurised reactor, this means that a new experiment must be run for every reaction time. All experimental results presented in this section are from a high-temperature separation of solid and liquid, according to sampling procedure (2) (Section 2.1). Fig. 7 shows the results of experiments with $3 \mathrm{gl}^{-1}$ of olivine slurry under the chosen conditions $\left(120^{\circ} \mathrm{C}, 20\right.$ bar of $\mathrm{CO}_{2}, 0.1 \mathrm{M}$ disodium oxalate).

During the first hour, olivine dissolution is fast and the magnesium that is leached out is present in aqueous form only. As soon as the concentration of $\mathrm{Mg}$ in solution reaches the saturation of glushinskite, $\mathrm{Mg}$ precipitates as glushinskite. It is our understanding that the subsequent decrease of free oxalate concentration slows down olivine dissolution, resulting in slope breakup after $4 \mathrm{~h}$. As ICP analysis does not differentiate between $\mathrm{Mg}$-oxalate ${ }_{(\mathrm{aq})} \mathrm{com-}$ plex and free $\mathrm{Mg}^{2+}$, the speciation of $\mathrm{Mg}$ had to be estimated from geochemical simulation (Section 3 ). The model predicts that the final amount of free oxalate $\mathrm{C}_{2} \mathrm{O}_{4}{ }^{2-}$ in solution is $0.066 \mathrm{moll}^{-1}$, i.e. 


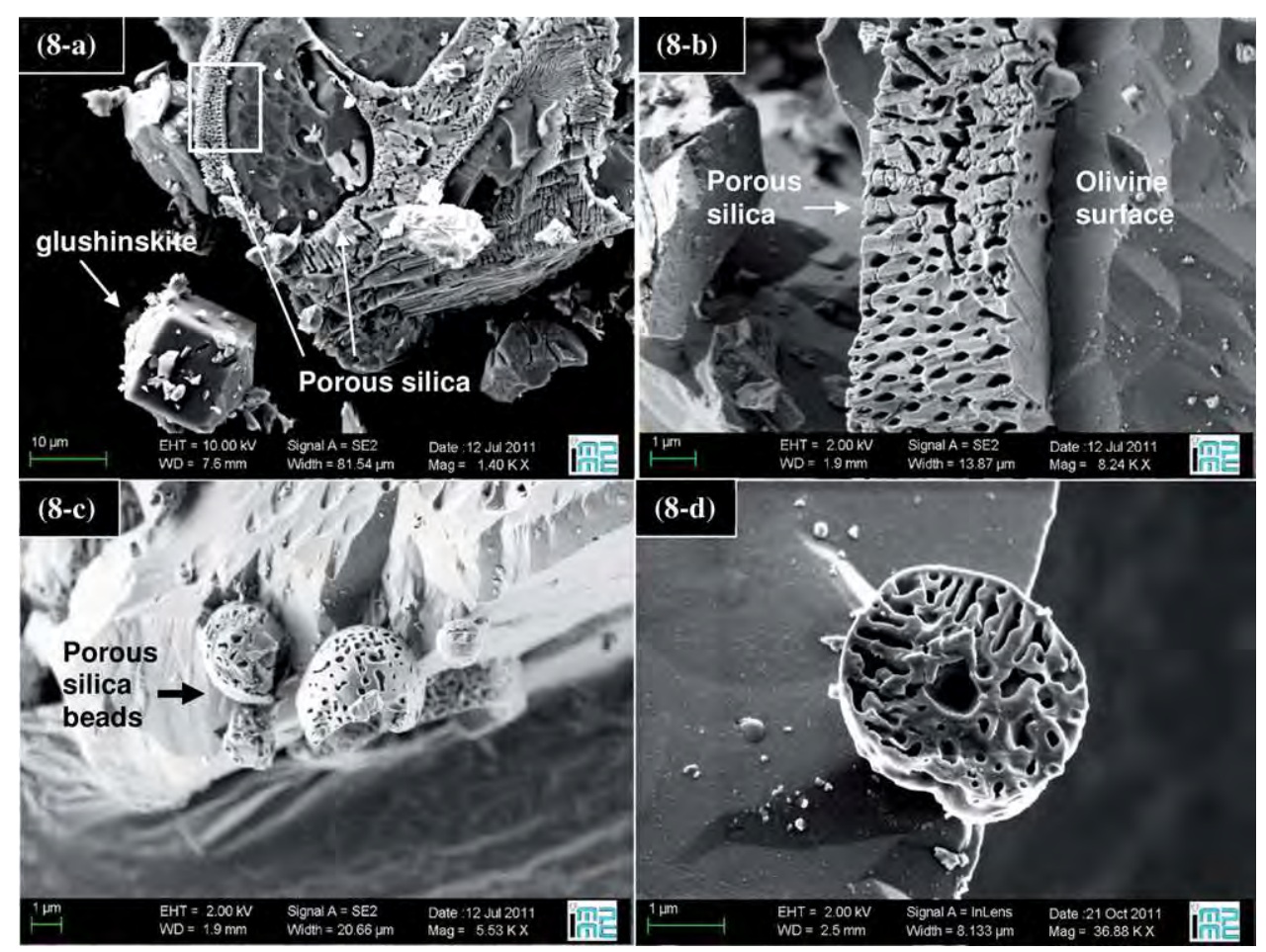

Fig. 8. FEG-SEM images of solid particles after $1 \mathrm{~h}$ of reaction $\left(3 \mathrm{gl}^{-1}\right.$ slurry with $0.1 \mathrm{M}$ oxalate salt, under $120^{\circ} \mathrm{C}$ and 20 bar of $\left.\mathrm{CO}_{2}\right)$. (a) An olivine particle partially covered by a porous silica layer; glushinskite crystals are observed. (b) The microstructure of the highly porous precipitated silica layer. (c and d) Micrometric porous silica beads on the olivine surface.

$35 \%$ of the initial oxalate is either precipitated as glushinskite or complexed as Mg-oxalate $(\mathrm{aq})$ in solution.

Precipitation of silica seems to happen later on. Indeed, during the first $6 \mathrm{~h}$ of reaction, the concentration of silicium in solution increases proportionally to the total amount of extracted magnesium. Eventually the concentration of aqueous silicium decreases and levels off at about $250 \mathrm{mg} \mathrm{l}^{-1}$, corresponding to an extraction yield of $40-45 \%$ at the end of the experiment. This concentration is higher than that we measured in the absence of ligand (approximately $80 \mathrm{mg} \mathrm{l}^{-1}$ ), which means that oxalate also has an effect on silica solubility and/or on its critical saturation for precipitation, delaying the formation of the silica layer on the particle surface.

The extraction of iron in solution does not exceed $60 \%$, because a significant fraction of iron in our initial material occurs as insoluble ferrous (III) oxides.

The residual solid was analysed by FEG-SEM/EDX after $1 \mathrm{~h}$ and $24 \mathrm{~h}$ of reaction, mainly to observe the precipitates (Figs. 8 and 9, respectively).

The images in Fig. 8 show deposition of silica on the surface of olivine particles after just $1 \mathrm{~h}$ of reaction. Many dissolution pits are visible on the surface. Fig. $8 \mathrm{a}$ and $\mathrm{b}$ also shows that deposition of silica is uneven on the surface of the olivine, leaving most of the surface uncovered. The uneven coverage of the particles by the silica is not sufficient to passivate the particle surface. Moreover, this silica appears to be highly porous. Fig. $8 \mathrm{c}$ also shows evidence of the silica phase forming porous beads. These observations are coherent with a shrinking particle or surface reaction controlled mechanism, i.e. without any significant diffusion barrier. They support the dissolution model applied by Krevor and Lackner (2011) with polyacid ligands. Fig. 8a also shows rhombohedral particles of glushinskite that precipitated away from the olivine particles.

The interesting highly porous microstructure of the silica deposits that form unevenly on the surface of the silicate particles is due to the presence of oxalate. Indeed, this texture is very different to that observed in water without additives, which consists of a much thinner and evenly distributed impervious layer that covers reactive surfaces (Béarat et al., 2006; Daval et al., 2011). A well-known difficulty with silica observations lies in differentiating between precipitation under experimental high pressure/high temperature conditions and quench effects. Indeed, silica microspheres due to quench are clearly observed in these experiments, on both olivine and glushinskite, and they are clearly distinct from the silica shown in Fig. 8 which is never present at the surface of glushinskite.

It may be concluded that oxalate has a triple beneficial action on olivine dissolution in that:

- it accelerates the dissolution kinetics by adsorbing on the mineral surface and weakening the $\mathrm{Mg}-\mathrm{O}$ bonds, as reported by Olsen and Rimstidt (2008) and Prigiobbe and Mazzotti (2011),

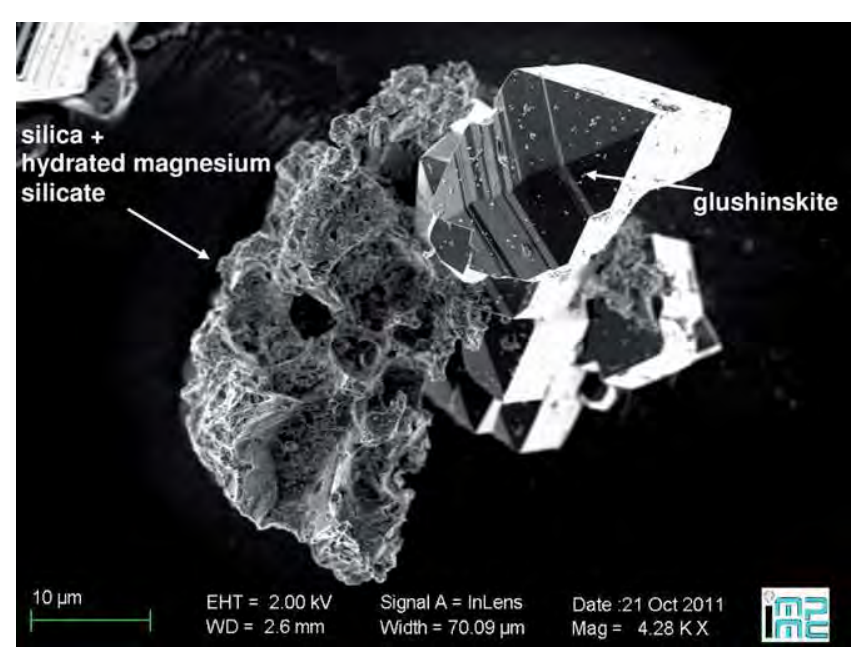

Fig. 9. FEG-SEM image of solid particles after $24 \mathrm{~h}$ of reaction $\left(3 \mathrm{gl}^{-1}\right.$ slurry with $0.1 \mathrm{M}$ oxalate salt, under $120^{\circ} \mathrm{C}$ and 20 bar of $\mathrm{CO}_{2}$ ). 


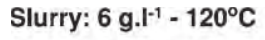
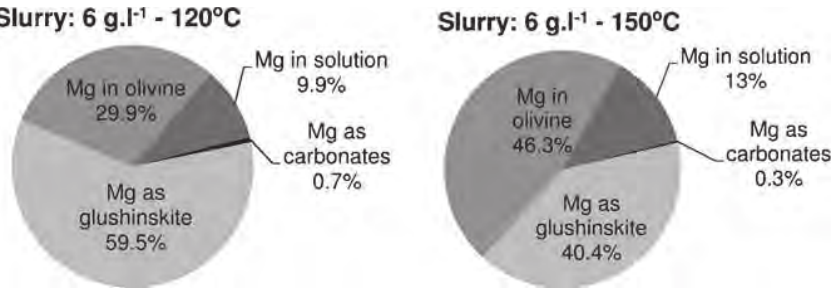

Fig. 10. Extraction yield and speciation of magnesium after $24 \mathrm{~h}$ with $6 \mathrm{gl}^{-1}$ slurry at $120^{\circ} \mathrm{C}$ and $150^{\circ} \mathrm{C}\left(0.1 \mathrm{M}\right.$ oxalate salt, 20 bar of $\left.\mathrm{CO}_{2}\right)$.

- it may increase the solubility of silicium in solution and/or modify the kinetics of silica (or silicate) precipitation,

- it changes the microstructure and porosity of the silica precipitate.

In the course of the reaction, silica changes progressively to a mixture between silica and a phyllosilicate (Fig. 9) with a microstructure that is clearly distinct from that of the silica observed at the beginning of the reaction. The chemical composition of this phyllosilicate is consistent with that of talc which, as will be seen in Section 3, is predicted by geochemical simulation. At the end of the reaction, the original particles have almost entirely disappeared, leaving only silica and phyllosilicate particles (smaller than the initial particles) and isolated glushinskite particles in the system, as confirmed by semi-quantitative EDX analysis in Fig. 9.

\subsubsection{Effect of temperature}

It is known that relatively small changes in temperature can lead to significant changes in precipitation with such geochemical systems. This justifies a short section about the effect of temperature on the formation of glushinskite in this article. It was initially observed that the amount of glushinskite formed at $120^{\circ} \mathrm{C}$ (after withdrawing all the liquid prior to cooling the reactor according to sampling procedure (2)) was less than the amount recovered when the whole system was allowed to cool down to room temperature as per sampling procedure (1). A $24 \mathrm{~h}$ test was conducted at $150^{\circ} \mathrm{C}$ with $6 \mathrm{gl}^{-1}$ of solids to add to this initial observation. Results are compared to those of the same experiment at $120^{\circ} \mathrm{C}$ in Fig. 10 .

Surprisingly the $150^{\circ} \mathrm{C}$ experiment shows a lower conversion of olivine and still a significant amount of magnesium precipitates as glushinskite. The loss of extraction efficiency might be in fact explained by some decomposition of oxalate above $125^{\circ} \mathrm{C}$ (Kettler et al., 1998), yielding a lower oxalate concentration in solution and
Table 3

Formation constants of various aqueous magnesium complexes at $25^{\circ} \mathrm{C}$ : (a) from Martell and Smith (2001), (b) from Prapaipong et al. (1999) and (c) in CTDP.

\begin{tabular}{ll}
\hline Complex & $\log _{10} K_{i}$ of reaction: \\
& $\mathrm{Mg}^{2+}+$ Ligand $\rightarrow$ Mg-Ligand \\
\hline MgEDTA $^{2-}$ & $8.96^{\mathrm{a}}$ \\
MgCitrate $^{-}$ & $4.89^{\mathrm{a}}$ \\
MgOxalate $_{(\mathrm{aq})}$ & $3.19^{\mathrm{b}}$ \\
Mg(Acetate $)_{2(\mathrm{aq})}$ & $1.80^{\mathrm{c}}$ \\
\hline
\end{tabular}

hence a lower reaction rate, which offsets the otherwise beneficial effect of increasing temperature.

\subsubsection{Comparison with other complexing agents}

Another set of experiments was carried out with other additives also known to increase dissolution of magnesium silicates: citrate and EDTA. Their aqueous complex with magnesium is even more stable than that with oxalate (Table 3 ). While this will promote olivine dissolution, it may yet again oppose the formation of magnesite.

As expected from its complexation constant with magnesium, citrate is as strong a dissolution enhancing agent as oxalate, but it did not yield any detectable solid by-product. EDTA, which is even a stronger complexing agent, increases the dissolution rate even more (cf. Fig. 11). Although these ligands do not yield any solid precipitate, they form too strong an aqueous complex with magnesium for magnesium to precipitate as carbonate. Even with $90 \mathrm{~g} \mathrm{l}^{-1}$ slurry, we found no evidence of any carbonate after $24 \mathrm{~h}$, the total extraction of magnesium being $11 \%$ with EDTA and 6\% with citrate. These findings extend our previous conclusion with oxalate in that polyacid additives are not a viable option for development of the direct aqueous mineral carbonation process. Another test was made using sodium acetate salt, and it was found in agreement with previous results obtained by Krevor and Lackner (2011) that dissolution is not different to that obtained with water only.

For the sake of completeness of this work, complementary experiments were performed on a natural harzburgite from NewCaledonia. This ore consists mainly of hydrated magnesium silicates - lizardite and clinochrysotile - associated with low amounts of forsterite and enstatite and traces of diopside. Dissolution yields were similar to those obtained with the olivine used in this work, both with diluted or concentrated slurry conditions, and precipitation of glushinskite was also observed in comparable amounts. The dissolution yields with this material and with the olivine are shown in Fig. 12. We can observe similar dissolution yields for both

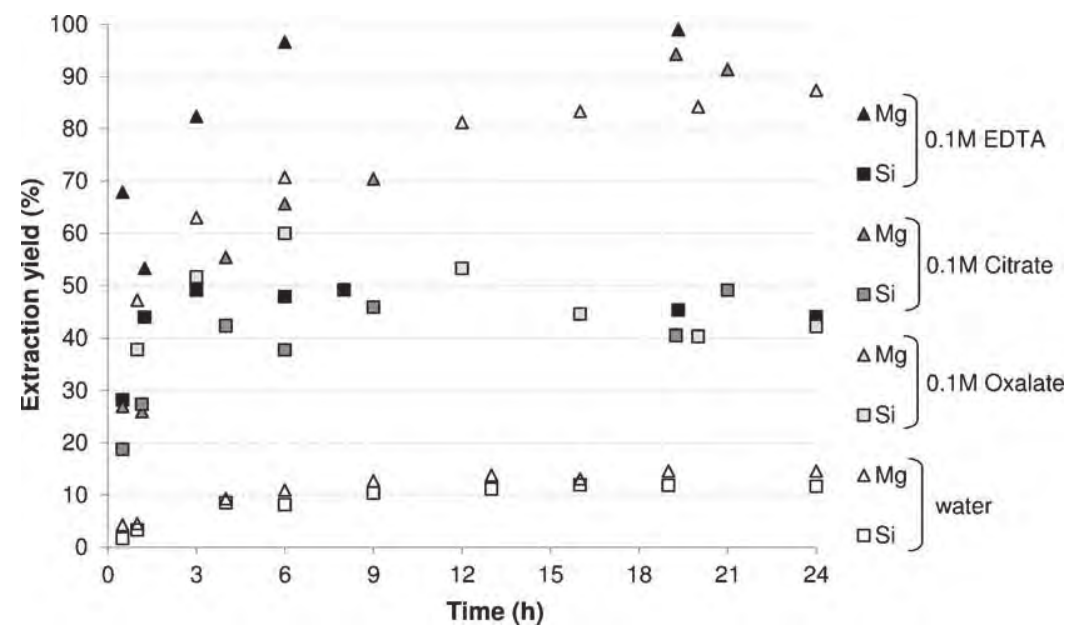

Fig. 11. Total amount of magnesium and silicium extracted for various aqueous solutions: without additive, with $0.1 \mathrm{M}$ of respectively, oxalate, citrate or EDTA salt ( $3 \mathrm{gl} \mathrm{l}^{-1}$ slurry with particle size $<100 \mu \mathrm{m}$, under $120^{\circ} \mathrm{C}$ and 20 bar of $\mathrm{CO}_{2}$ ). 


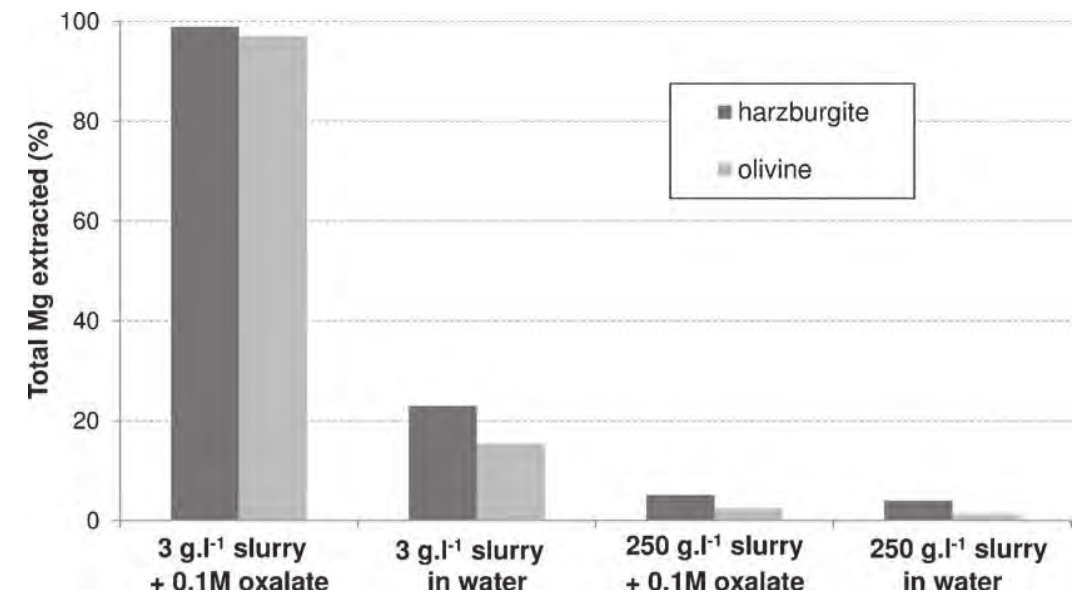

Fig. 12. Comparison of magnesium extraction yields in water and with $0.1 \mathrm{M}$ oxalate, for olivine and harzburgite $\left(3 \mathrm{gl}^{-1}\right.$ and $250 \mathrm{gl}^{-1}$ slurries under $120{ }^{\circ} \mathrm{C}$ and 20 bar of $\left.\mathrm{CO}_{2}\right)$.

concentrated $\left(250 \mathrm{gl}^{-1}\right)$ and diluted $\left(3 \mathrm{gl}^{-1}\right)$ slurries. The surprisingly lower yield observed with olivine is thought to be caused by the higher specific surface area of ground harzburgite, with $12.7 \mathrm{~m}^{2} \mathrm{~g}^{-1}$ against $0.58 \mathrm{~m}^{2} \mathrm{~g}^{-1}$ for olivine. These results strengthen our previous conclusions that organic ligands are not a feasible option for development of a direct aqueous carbonation process.

\section{Reaction modelling and system analysis by simulation}

To complete the analysis of the magnesium silicate-polyacid system, a geochemical modelling study was undertaken. The dissolution of olivine with sodium oxalate under our experimental conditions $\left(120^{\circ} \mathrm{C}\right.$ and 20 bar of $\mathrm{CO}_{2}$ pressure) was modelled using the CHESS geochemical modelling software (van der Lee, 2007). Development steps included:

- updating the thermodynamic database to account for all observed species formed from the silicate-oxalate system,

- selecting a model for the reaction,

- optimising some kinetic parameters using the experimental data presented in Section 2.

\subsection{Thermodynamics analysis and update}

The CTPD database (Common Thermodynamic Data Project, www.ctdp.org) was used in this study. Magnesium oxalate was not included in the original version of the CTDP database, neither in aqueous complex nor in solid forms. Aqueous ferrous oxalate complex was also missing. For the aqueous complexes, we used the SLOP92 database which gives reliable equilibrium constants at various temperatures for both ferrous oxalate and magnesium oxalate. Only one equilibrium constant value was found in the literature for glushinskite at $25^{\circ} \mathrm{C}$ : $\log _{10}\left(K_{\mathrm{s}, 25}{ }^{\circ} \mathrm{C}\right)=5.31$ according to $\mathrm{Mg}^{2+}+\mathrm{C}_{2} \mathrm{O}_{4}^{2-}+2 \mathrm{H}_{2} \mathrm{O} \rightarrow \mathrm{MgC}_{2} \mathrm{O}_{4} \cdot 2 \mathrm{H}_{2} \mathrm{O}$ (Lichstein and Brescia, 1957). Hence, we measured its solubility product at $120^{\circ} \mathrm{C}$ using aqueous solutions of $\mathrm{MgCl}_{2}$ and $\mathrm{Na}_{2} \mathrm{C}_{2} \mathrm{O}_{4}$. A solution consisting of $0.1 \mathrm{M} \mathrm{MgCl}$ and $0.1 \mathrm{M} \mathrm{Na}_{2} \mathrm{C}_{2} \mathrm{O}_{4}$ was heated to $120^{\circ} \mathrm{C}$ and let to react for $1 \mathrm{~h}$ to ensure equilibrium, even though precipitation is probably instantaneous. The experiment yielded pure glushinskite and gave $\log _{10}\left(K_{\mathrm{s}, 120^{\circ} \mathrm{C}}\right)=6.24$.

We modelled dissolution of our olivine by using the properties of forsterite $\mathrm{Mg}_{2} \mathrm{SiO}_{4}$, which is the main constituent in this material. This means that the "model olivine" was given the same thermodynamic properties as those of the default CTDP forsterite $\mathrm{Mg}_{2} \mathrm{SiO}_{4}$. For sake of mass balance, the stoichiometric formula of the "model olivine" was adjusted to match the actual Fe and Mg content of Table 1 and to satisfy the electroneutrality assumption. Then the dissolution was assumed to be stoichiometric between magnesium and iron, as if iron was homogeneously distributed inside the olivine particles. The activities of aqueous species are all computed in this section with the Debye-Hückel model.

\subsection{Shrinking particle model}

Based on the findings presented in Section 2, a shrinking particle model controlled by chemical surface reaction was chosen to describe the dissolution of olivine. As mentioned before, the particle size distribution was approximated as 20 distinct particle size classes derived from the full surface-weighted particle size distribution (Table 2). One particle type had to be input into CHESS for every size class, which partly explains why it was decided to reduce the number of classes to 20 for describing the actual particle size distribution. Assuming that each size class is made of monodisperse spherical particles, instantaneous mass balance for individual size classes can be calculated from (Levenspiel, 1999):

$\frac{\mathrm{d} n_{B}}{\mathrm{~d} t}=-r \cdot \mathrm{SSA}_{0} \cdot w_{0}\left(\frac{n_{B}(t)}{n_{B 0}}\right)^{2 / 3}$

where $n_{B}$ is the number of moles of olivine in the considered class ( $n_{B 0}$ at initial time), $\mathrm{SSA}_{0}$ its corresponding specific surface area, $w_{0}$ its initial weight and $r$ the surface reaction rate (given by Eq. (2)). Eq. (4) was solved using the lattice model option from CHESS (van der Lee, 2007) which controls the variation of the reactive surface A according to:

$A=A_{0}\left(\frac{n_{B}}{n_{B 0}}\right)^{2 / 3}$

with $A_{0}$ the initial particle surface $\left(\mathrm{m}^{2}\right)$.

The Langmuir type term found in Eq. (2) was reformulated so as to match the generalised Monod term available in CHESS:

$$
\begin{aligned}
M & =\prod_{i}\left[\frac{S_{i}^{m_{1 i}}}{K_{i}^{m_{1 i}}+S_{i}^{m_{1 i}}}\right]^{m_{2 i}} \Leftrightarrow \frac{a_{\mathrm{ox}}^{-1}}{K_{x}+a_{\mathrm{ox}}^{-1}} \times\left[\frac{a_{\mathrm{ox}}^{-1}}{\beta K_{x}+a_{\mathrm{ox}}^{-1}}\right]^{-1} \\
& =\frac{1+\beta K_{x} a_{\mathrm{ox}}}{1+K_{x} a_{\mathrm{ox}}}
\end{aligned}
$$

with $S_{i}$ the concentration (or activity if needed) of chosen species (in our case the oxalate ion $\mathrm{C}_{2} \mathrm{O}_{4}{ }^{2-}$ ), $m_{1 i}, m_{2 i}$ and $K_{i}$ free CHESS parameters set to adequate values. 


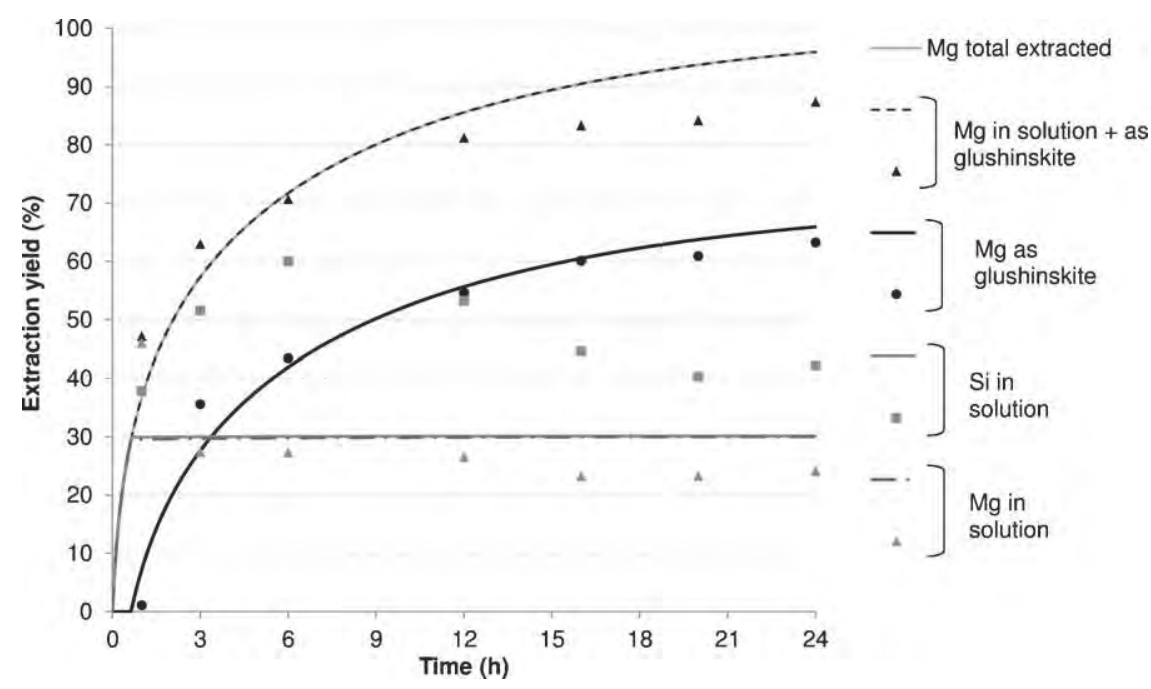

Fig. 13. Comparison between experimental data and shrinking particle simulation results assuming instantaneous precipitation of amorphous silica $\left(3 \mathrm{~g} \mathrm{l}^{-1}\right.$ slurry with $0.1 \mathrm{M}$ oxalate salt, under $120^{\circ} \mathrm{C}$ and 20 bar of $\mathrm{CO}_{2}$ ).

The conversion of the 20 size classes is calculated simultaneously, and the speciation of magnesium and silicium in solution is directly calculated by CHESS, from which the overall extraction yield is deduced.

The corresponding CHESS code that was implemented to model the dissolution rate of olivine can be found in the supplementary data.

\subsection{Dissolution rate and results}

In our initial simulation, we applied the surface reaction rate published by Prigiobbe and Mazzotti (2011) directly. In their model, parameters from Eqs. (2) and (3) are $A=2640 \mathrm{~mol} \mathrm{~m}^{-2} \mathrm{~s}^{-1}, n=0.52$, $E_{a}=52.9 \mathrm{~kJ} \mathrm{~mol}^{-1}, \beta=71$ and $K_{x}=10$. As mentioned above, the formation constant of glushinskite was set to $\log _{10}\left(K_{\mathrm{s}, 120^{\circ} \mathrm{C}}\right)=6.24$.

Fig. 13 shows that the result of this simulation (without any parameter fitting) already gives a reasonable match to the observed total magnesium extraction rate and glushinskite formation rate.

The predicted speciation of magnesium after $24 \mathrm{~h}$ of reaction is pictured in Fig. 14.

Prediction of glushinskite formation according to thermodynamic equilibrium agrees well with the experimental values, which means that its precipitation kinetics is fast compared to the magnesium extraction.

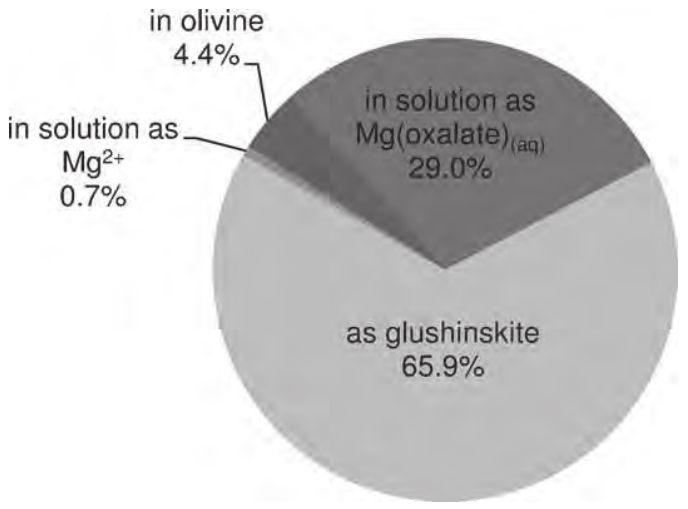

Fig. 14. Speciation of magnesium from first simulation assuming instantaneous precipitation of amorphous silica ( $3 \mathrm{~g} \mathrm{l}^{-1}$ slurry with $0.1 \mathrm{M}$ oxalate salt, under $120^{\circ} \mathrm{C}$ and 20 bar of $\mathrm{CO}_{2}$ ).
However, precipitation kinetics of other solid species is not instantaneous. Indeed, the simulation predicts that the aqueous silicium concentration levels off after $1 \mathrm{~h}$ reaction time, which coincides with the start of the precipitation of amorphous silica $\mathrm{SiO}_{2(\mathrm{am})}$. It plateaus at a value lower than the experimental one.

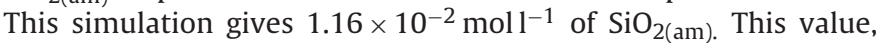
which could not be measured experimentally, as well as the discrepancy between measurements and simulation in the case of aqueous silicium, illustrates the value of coupling simulation with experimental results for investigating such complex geochemical systems. In this case the description of silica precipitation should be improved as silicium concentration in solution exhibits a maximum that was not predicted by the first model.

As the precipitation rate for amorphous silica is clearly not instantaneous, it was accounted for in a second simulation using

$$
\frac{\mathrm{d} m_{\mathrm{SiO}_{2(\mathrm{am})}}}{\mathrm{d} t}=k_{\mathrm{SiO}_{2(\mathrm{am})}}\left(\Omega_{\mathrm{SiO}_{2(\mathrm{am})}}-1\right)
$$

An interesting outcome is that with this kinetic model, simulation with CHESS predicts the precipitation of talc together with that of amorphous silica. Talc is a hydrated magnesium silicate with chemical formula $\mathrm{Mg}_{3} \mathrm{Si}_{4} \mathrm{O}_{10}(\mathrm{OH})_{2}$. This composition is consistent with the presence of magnesium measured within silica rich particles (Fig. 9). Although the true nature of the phyllosilicate present in these experiments remains to be determined, we assumed for modelling purposes that it was talc, as predicted by the simulation. The kinetic model used for amorphous silica was also used to model the precipitation of talc:

$\frac{\mathrm{d} m_{\mathrm{talc}}}{\mathrm{d} t}=k_{\mathrm{talc}}\left(\Omega_{\mathrm{talc}}-1\right)$

Eqs. (7) and (8) only come into play when the corresponding solid species become oversaturated, i.e. when $\Omega_{i}=Q_{i} / K_{\mathrm{Si}}>1$, which brings them back to precipitation equilibrium $\left(\Omega_{i}=1\right)$.

The corresponding CHESS code implemented to model these precipitation rates can be found in the supplementary data attached to this article.

The kinetic constants for amorphous silica and talc were determined by matching CHESS predicted and measured aqueous silica concentrations using a Levenberg-Marquardt regression algorithm. The estimated rate constants are $k_{\mathrm{SiO}_{2(\mathrm{am})}}=$ $2.17 \times 10^{-7}$ molal s$^{-1}$ and $k_{\text {talc }}=3.28 \times 10^{-8}$ molal s$^{-1}$. The results of this second simulation are shown in Figs. 15 and 16. 


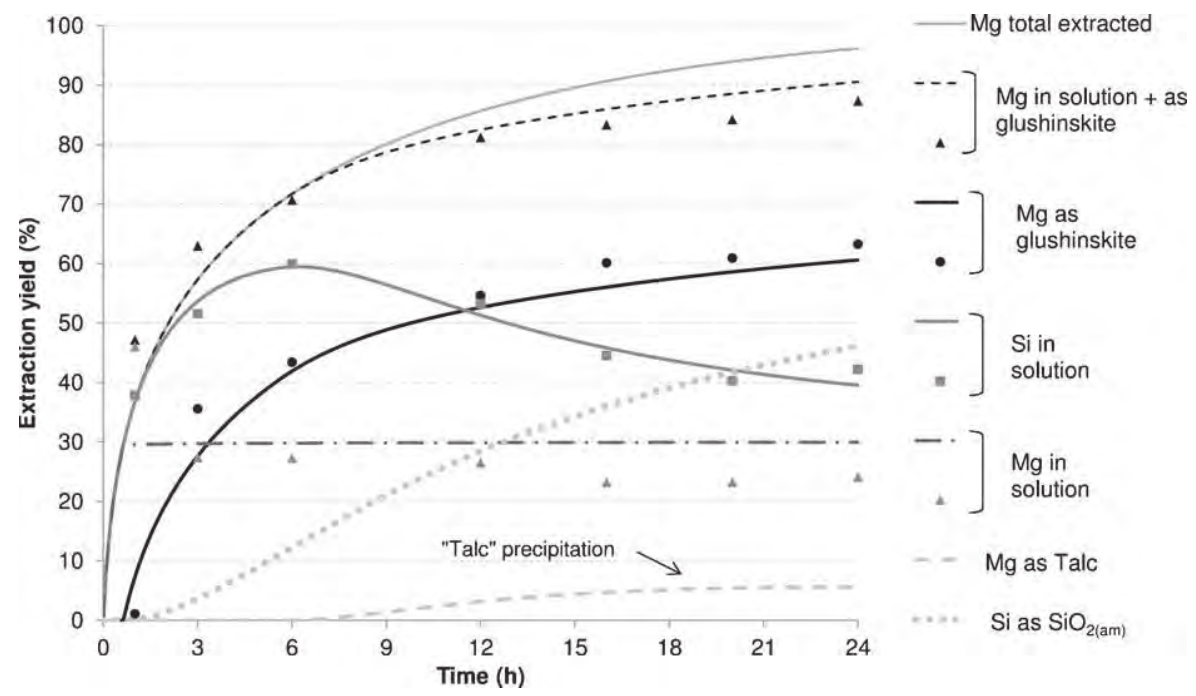

Fig. 15. Comparison between experimental data and shrinking particle simulation results when accounting for precipitation kinetics of amorphous silica and talc $\left(3 \mathrm{~g} \mathrm{l}^{-1}\right.$ slurry with $0.1 \mathrm{M}$ oxalate salt, under $120^{\circ} \mathrm{C}$ and 20 bar of $\mathrm{CO}_{2}$ ).

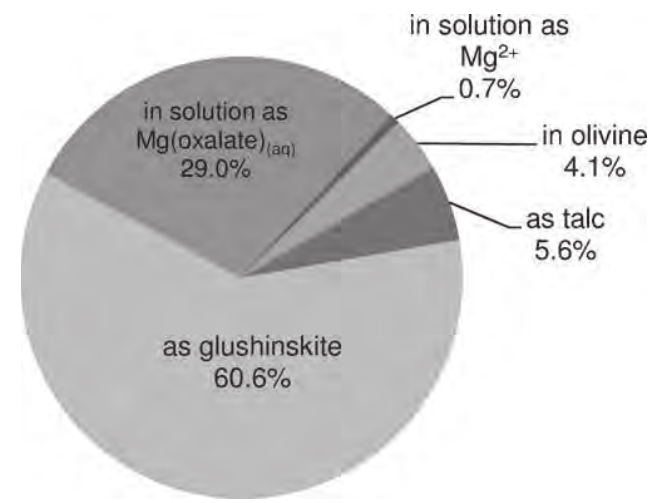

Fig. 16. Predicted speciation of magnesium after $24 \mathrm{~h}$ of reaction when accounting for precipitation kinetics of amorphous silica and talc ( $3 \mathrm{gl}^{-1}$ slurry with $0.1 \mathrm{M}$ oxalate salt, under $120^{\circ} \mathrm{C}$ and 20 bar of $\mathrm{CO}_{2}$ ).

As expected, the predicted evolution of aqueous silicium concentration now matches the observations. This also affects the speciation of extracted magnesium, and predictions of both the aqueous magnesium and glushinskite match the observations more closely than with the initial simulation. After $24 \mathrm{~h}$ of reaction, the amounts of $\mathrm{SiO}_{2(\mathrm{am})}$ and talc are found to be, respectively, $1.13 \times 10^{-2} \mathrm{moll}^{-1}$ and $6.4 \times 10^{-4} \mathrm{moll}^{-1}$ (equivalent to $5.6 \%$ of initial magnesium for the latter).

Our geochemical simulation completes our understanding of magnesium silicate dissolution in the presence of oxalate. It confirms that

- a shrinking particle model is the correct model for describing the dissolution behaviour of olivine in the presence of oxalate ligand,

- there is a strong interaction between magnesium and oxalate ions, both in liquid and solid phases,

- precipitation of magnesite is hindered because of the low activity of free $\mathrm{Mg}^{2+}$ in solution,

- precipitation of a phyllosilicate occurs together with that of amorphous silica at advanced stages of the dissolution process.

\section{Conclusions}

The objective of this work was to investigate and possibly conclude on the feasibility of direct aqueous mineral carbonation using polyacid organic salts. Temperature and $\mathrm{CO}_{2}$ partial pressure levels were matched to conditions found in the mineral carbonation literature for promoting silicate dissolution with these additives, typically $120^{\circ} \mathrm{C}$ and 20 bar of $\mathrm{CO}_{2}$, which are also deemed suitable conditions for an industrial process.

It was found that oxalate has a multiple beneficial action on olivine dissolution, as it accelerates the dissolution kinetics by adsorbing on the mineral surface, it increases the solubility of silicium in solution and it modifies the microstructure of precipitated silica.

Nevertheless, it was also found that the strength of the complexation effect that makes polycarboxylic ligands so efficient for silicate dissolution is also their weakness, as their presence hinders the precipitation of magnesite. Most of the Mg extracted from the solid was shown to be bound to the ligand, either in solution or as a secondary solid phase. In the end, the $\mathrm{Mg}^{2+}$ available to form carbonates never exceeded $1 \%$ of the total $\mathrm{Mg}$. Higher slurry concentrations made no improvement as the organic anion becomes readily depleted before any significant dissolution can occur. It might be interesting to determine whether the enhancement of dissolution could be maintained at much lower anionic ligand concentrations, which might be an option for reaching magnesium carbonate saturation. Nonetheless, within the conditions used in this investigation $\left(120^{\circ} \mathrm{C}, 20\right.$ bar of $\mathrm{CO}_{2}, 0.1 \mathrm{M}$ of additive, $3-250 \mathrm{gl}^{-1}$ of ore), this work concludes that direct aqueous mineral carbonation with polycarboxylic salts is not a viable option for mineral carbonation.

It was found that analyses of liquid and solid phases are both required to understand the reaction mechanisms. In addition, some of the secondary products being difficult to identify or quantify, geochemical simulation proved to be indispensable for analysis of these geochemical systems. In fact, it proved necessary to go to and from between simulations and experiments throughout this work to overcome (i) the lack of thermodynamic data pertaining to such complex systems and (ii) the difficulty with direct observation of some of the solid phases formed during reactions.

Through dedicated experiments, speciation of magnesium and silicium was monitored during the whole process. Once the dissolution mechanisms had been revealed through detailed analysis of solid and liquid phases, a kinetic model was developed that predicts the experimental data quite well. Our geochemical simulation completes our understanding of magnesium silicate dissolution in the presence of oxalate. It shows that a shrinking particle model 
satisfactorily describes the dissolution behaviour of our olivine in the presence of oxalate ligand, and reveals that precipitation of magnesite is hindered because of the low activity of free $\mathrm{Mg}^{2+}$ in solution. It also confirms the experimental observation that amorphous silica precipitates at early stages of dissolution and that it is accompanied by precipitation of a phyllosilicate, most likely talc, at later stages of dissolution. This phyllosilicate formation is also detrimental for magnesite formation.

\section{Acknowledgements}

This research work has been conducted as part of the CARMEX project no. ANR-08-PCO2-002, which is funded by the Agence Nationale de Recherche (the French National Research Agency) through the $\mathrm{CO}_{2}$ Capture and Storage program. The authors also thank the oil and gas company TOTAL for funding the PhD grant of B. Bonfils.

Finally, they acknowledge Jean-Louis Labat, Alain Müller and Lahcen Farhi (LGC, INP Toulouse) for their contribution to the design and implementation of the experimental set-up, Thierry Augé (BRGM Orléans) for providing the starting material, Christine Rey-Rouch, Colin Fourtet, Marie-Line de Solan Bethmale (SAP, LGC Toulouse), Sandrine Desclaux, Sébastien Teychené, Nicolas Estime (LGC Toulouse), Philippe Besson (LMTG Toulouse), Serge Alamercery (SCA CNRS Lyon), Véronique Jean-Prost (BRGM Orléans), Matthieu Galvez (IMPMC, Paris), Olivier Sissmann (IPG/ENS Paris) for the physico-chemical analyses of the solids and solutions.

\section{Appendix A. Supplementary data}

Supplementary data associated with this article can be found, in the online version, at http://dx.doi.org/10.1016/j.ijggc. 2012.05.009

\section{References}

Bennett, P.C., 1991. Quartz dissolution in organic-rich aqueous systems. Geochimica et Cosmochimica Acta 55, 1781-1797.

Bonfils, B., Bourgeois, F., Julcour, C., Guyot, F., Chiquet, P., 2010. About the foundations of direct aqueous carbonation with dissolution enhancing organic salts. In: Accelerated Carbonation for Environmental and Material Engineering Conference, Turku, Finland.

Bonfils, B., Bourgeois, F., Julcour, C., Guyot, F., Chiquet, P., 2011. Understanding the chemistry of direct aqueous carbonation with additives through geochemica modelling. Energy Procedia 4, 3809-3816.

Béarat, H., McKelvy, M.J., Chizmeshya, A.V.G., Gormley, D., Nunez, R., Carpenter, R.W. Squires, K., Wolf, G.H., 2006. Carbon sequestration via aqueous olivine minera carbonation. Role of passivating layer formation. Environmental Science and Technology 40, 4802-4808.

Carey, J.W., Ziock, H.-J., Guthrie Jr., G.D., 2004. Reactivity of serpentine in $\mathrm{CO}_{2}$ bearing solutions: application to $\mathrm{CO}_{2}$ sequestration. American Chemical Society, Division of Fuel Chemistry 49 (1), 371-372.

Chen, Z.Y., O'Connor, W.K., Gerdemann, S.J., 2006. Chemistry of aqueous mineral carbonation for carbon sequestration and explanation of experimental results. Environmental Progress 25, 161-166.

Daval, D., Martinez, I., Corvisier, J., Findling, N., Goffé, B., Guyot, F., 2009. Carbonation of Ca-bearing silicates, the case of wollastonite: experimental investigations and kinetic modeling. Chemical Geology 265, 63-78.

Daval, D., Sissmann, O., Menguy, N., Saldi, G.D., Guyot, F., Martinez, I., Corvisier, J., Garcia, B., Machouk, I., Knauss, K.G., Hellmann, R., 2011. Influence of amorphous silica layer formation on the dissolution rate of olivine at $90^{\circ} \mathrm{C}$ and elevated $p_{\mathrm{CO} 2}$. Chemical Geology 284, 193-209.

D’Antonio, M.C., Mancilla, N., Wladimirsky, A., Palacios, D., González-Baró, A.C. Baran, E.J., 2010. Vibrational spectra of magnesium oxalates. Vibrational Spectroscopy 53, 218-221.

Gerdemann, S.J., O'Connor, W.K., Dahlin, D.C., Penner, L.R., Rush, H., 2007. Ex situ aqueous mineral carbonation. Environmental Science and Technology 41, 2587-2593.

Goff, F., Lackner, K.S., 1998. Carbon dioxide sequestering using ultramafic rocks. Environmental Geosciences 5, 89-101.

Goff, F., Guthrie, G.D., Lipin, B., Fite, M., Chipera, S.J., Counce, D.A., Kluk, E., Ziock, H. 2000. Evaluation of ultramafic deposits in the eastern United States and Puerto Rico as sources of magnesium for carbon sequestration. Report LA-13693-MS, Los Alamos Nat. Lab.

Hänchen, M., Prigiobbe, V., Storti, G., Seward, T.M., Mazotti, M., 2006. Dissolution kinetics of fosteritic olivine at $90-150^{\circ} \mathrm{C}$ including effect of the presence of $\mathrm{CO}_{2}$. Geochimica et Cosmochimica Acta 70, 4403-4416.

Hänchen, M., Prigiobbe, V., Baciocchi, R., Mazotti, M., 2008. Precipitation in the $\mathrm{Mg}$-carbonate system-effects of temperature and $\mathrm{CO}_{2}$ pressure. Chemical Engineering Science 63, 1012-1028.

Huijgen, W.J.J., Witkamp, G.-J., Comans, R.N.J., 2006. Mechanisms of aqueous wollastonite carbonation as a possible $\mathrm{CO}_{2}$ sequestration process. Chemical Engineering Science 61, 4242-4251.

Kettler, R.M., Wesolowski, D.J., Palmer, D.A., 1998. Dissociation constants of oxalic acid in aqueous sodium chloride and sodium trifluoromethanesulfonate media to $175^{\circ} \mathrm{C}$. J. Chem. Eng. Data $43,337-350$.

Krevor, S.C., Lackner, K.S., 2009. Enhancing process kinetics for mineral carbon sequestration. Energy Procedia 1, 4867-4871.

Krevor, S.C., Lackner, K.S., 2011. Enhancing serpentine dissolution kinetics for mineral carbon dioxide sequestration. International Journal of Greenhouse Gas Control 5, 1073-1080.

Lackner, K.S., Wendt, C.H., Butt, D., Joyce Jr., E., Sharp, D., 1995. Carbon dioxide disposal in carbonate minerals. Energy 20, 1153-1170.

Levenspiel, O., 1999. Chemical Reaction Engineering, 3rd ed. John Wiley and Sons.

Lichstein, B., Brescia, F., 1957. The mechanism of the precipitation of magnesium oxalate from supersaturated solution. 2 . The heat and entropy of activation. Journal of the American Chemical Society 79 (7), 1591-1592.

Liu, Y., Olsen, A.A., Rimstidt, J.D., 2006. Mechanism for the dissolution of olivine series minerals in acidic solutions. American Mineralogist 91, 455-458.

Martell, A.M., Smith, R.M., 2001. NIST Critically Selected Stability Constants of Metal Complexes Database. Plenum Press.

Metz, B., Davidson, O., De Coninck, H., Loos, M., Meyer, L., 2005. Special Report on Carbon Dioxide Capture and Storage. Intergovernmental Panel on Climate Change (IPCC).

Newall, P.S., Clarke, S.J., Haywood, H.M., Scholes, H., Clarke, N.R., King, P.A., Barley, R.W., 1999. $\mathrm{CO}_{2}$ storage as carbonates minerals. PH 3/17. IEA Greenhouse Gas R\&D Programme.

O'Connor, W.K., Dahlin, D.C., Nielsen, D.N., Rush, G.E., Walters, R.P., Turner, P.C., 2001 Carbon dioxide sequestration by direct mineral carbonation: results from recent studies and current status. DOE/ARC-2001-029, Albany Research Center.

Olsen, A.A., Rimstidt, J.D., 2008. Oxalate-promoted forsterite dissolution at low pH. Geochimica et Cosmochimica Acta 72, 1758-1766.

Park, A.H.A., Fan, L.S., 2004. $\mathrm{CO}_{2}$ Mineral sequestration. Physically activated dissolution of serpentine and pH swing process. Chemical Engineering Science 59, 5241-5247.

Poulson, S.R., Drever, J.I., Stillings, L.L., 1997. Aqueous Si-oxalate complexing oxalate adsorption onto quartz, and the effect of oxalate upon quartz dissolution rates. Chemical Geology 140, 1-7.

Prapaipong, P., Shock, E.L., Koretsky, C.M., 1999. Metal-organic complexes in geochemical processes: temperature dependence of the standard thermodynamic properties of aqueous complexes between metal cations and dicarboxylate ligands. Geochimica et Cosmochimica Acta 63, 2547-2577.

Prigiobbe, V., Mazzotti, M., 2011. Dissolution of olivine in the presence of oxalate citrate, and $\mathrm{CO}_{2}$ at $90^{\circ} \mathrm{C}$ and $120^{\circ} \mathrm{C}$. Chemical Engineering Science 66 , 6544-6554

Teir, S., Revitzer, H., Eloneva, S., Fogelholm, C.J., Zevenhoven, R., 2007. Dissolution of natural serpentine in mineral and organic acids. International Journal of Mineral Processing 83, 36-46.

van der Lee, J., 2007. Reactive transport modelling with HYTEC. In: User's Guide and Tutorial. User's Guide Nr. LHM/RD/05/30. Ecole des Mines de Paris, Fontainebleau, France.

Wogelius, R.A., Walther, J.V., 1991 . Olivine dissolution at $25^{\circ} \mathrm{C}$ : effects of $\mathrm{pH}, \mathrm{CO}_{2}$, and organic acids. Geochimica et Cosmochimica Acta 55, 943-954. 